medRxiv preprint doi: https://doi.org/10.1101/2021.10.14.21265023; this version posted October 16, 2021. The copyright holder for this preprint (which was not certified by peer review) is the author/funder, who has granted medRxiv a license to display the preprint in perpetuity.

It is made available under a CC-BY-NC-ND 4.0 International license .

\title{
Genetic associations of protein-coding variants in human disease
}

Benjamin B. Sun ${ }^{* 1,2}$, Mitja I. Kurki ${ }^{3,4,5,6}$, Christopher N. Foley ${ }^{7,8}$, Asma Mechakra ${ }^{9}$, Chia-Yen Chen $^{1}$, Eric Marshall ${ }^{1}$, Jemma B. Wilk ${ }^{1}$, Biogen Biobank Team ${ }^{1}$, Mohamed Chahine ${ }^{10}$, Philippe Chevalier ${ }^{9}$, Georges Christé ${ }^{9}$, FinnGen $^{11}$, Aarno Palotie ${ }^{3,4,5,6}$, Mark J. Daly ${ }^{3,4,5,6}$, Heiko Runz ${ }^{* 1}$.

1. Translational Biology, Research \& Development, Biogen Inc., Cambridge, MA, US

2. BHF Cardiovascular Epidemiology Unit, Department of Public Health and Primary Care, University of Cambridge, Cambridge, UK

3. Psychiatric \& Neurodevelopmental Genetics Unit, Massachusetts General Hospital, Boston, MA, US

4. The Stanley Center for Psychiatric Research, The Broad Institute of MIT and Harvard, Cambridge, MA, US

5. Institute for Molecular Medicine Finland (FIMM), University of Helsinki, Helsinki, Finland

6. Analytic and Translational Genetics Unit, Department of Medicine, Massachusetts General Hospital, Boston, MA, US

7. MRC Biostatistics Unit, School of Clinical Medicine, University of Cambridge, Cambridge, UK

8. Optima Partners, Edinburgh, UK

9. Université Claude Bernard Lyon 1, EA4612 Neurocardiology, Lyon, France

10. CERVO Brain Research Center and Department of Medicine, Faculty of Medicine, Université Laval, Quebec City, QC, Canada

11. FinnGen, Finland

*Correspondence: bbsun92@,outlook.com (B.B.S.), heiko.runz@gmail.com (H.R.) 
medRxiv preprint doi: https://doi.org/10.1101/2021.10.14.21265023; this version posted October 16, 2021. The copyright holder for this preprint (which was not certified by peer review) is the author/funder, who has granted medRxiv a license to display the preprint in It is made available under a CC-BY-NC-ND 4.0 International license .

\section{Abstract}

26 Genome-wide association studies (GWAS) have identified thousands of genetic variants linked

27 to the risk of human disease. However, GWAS have thus far remained largely underpowered

28 to identify associations in the rare and low frequency allelic spectrum and have lacked the resolution to trace causal mechanisms to underlying genes. Here, we combined whole exome sequencing in 392,814 UK Biobank participants with imputed genotypes from 260,405 FinnGen participants $(653,219$ total individuals) to conduct association meta-analyses for 744

32 disease endpoints across the protein-coding allelic frequency spectrum, bridging the gap between common and rare variant studies. We identified 975 associations, with more than one-

34 third of our findings not reported previously. We demonstrate population-level relevance for mutations previously ascribed to causing single-gene disorders, map GWAS associations to

36 likely causal genes, explain disease mechanisms, and systematically relate disease associations to levels of 117 biomarkers and clinical-stage drug targets. Combining sequencing and genotyping in two population biobanks allowed us to benefit from increased power to detect and explain disease associations, validate findings through replication and propose medical

40 actionability for rare genetic variants. Our study provides a compendium of protein-coding 41 variant associations for future insights into disease biology and drug discovery. 
medRxiv preprint doi: https://doi.org/10.1101/2021.10.14.21265023; this version posted October 16, 2021. The copyright holder for this preprint (which was not certified by peer review) is the author/funder, who has granted medRxiv a license to display the preprint in It is made available under a CC-BY-NC-ND 4.0 International license .

\section{Introduction}

44 Inherited protein-coding and non-coding DNA variations play a role in the risk, onset, and progression of human disease. Traditionally, geneticists have dichotomized diseases as either caused by coding mutations in single genes that tend to be rare, highly penetrant, and often compromise survival and reproduction (often termed "Mendelian" diseases), or alternatively as common diseases that show a complex pattern of inheritance influenced by the joint contributions of hundreds of low-impact, typically non-coding genetic variants (often termed "complex" diseases). For both rare and common conditions, large human cohorts systematically characterized for a respective trait of interest have enabled the identification of thousands of disease-relevant variants through either sequencing-based approaches or genomewide association studies (GWAS). Nevertheless, the exact causal alleles and mechanisms that underlie associations of genetic variants to disease have thus far remained largely elusive ${ }^{1}$.

In recent years, population biobanks have been added to the toolkit for disease gene discovery. Biobanks provide the opportunity to simultaneously investigate multiple traits and diseases at once and uncover relationships between previously unconnected phenotypes. For instance, the UK Biobank (UKB) is a resource that captures detailed phenotype information matched to genetic data for over 500,000 individuals and, since its inception, has facilitated biomedical discoveries at an unprecedented scale ${ }^{2}$. We and others have recently reported on the ongoing efforts to sequence the exomes of all UKB participants and link genetic findings to a broad range of phenotypes ${ }^{3-5}$. We also established FinnGen (FG), an academic-industry collaboration to identify genotype-phenotype correlations in the Finnish founder population with the aim to better understand how the genome affects health (https://www.finngen.fi). Finland is a wellestablished genetic isolate and a unique gene pool distinguishes Finns from other Europeans ${ }^{6}$. The distinct Finnish haplotype structure is characterized by large blocks of co-inherited DNA 
medRxiv preprint doi: https://doi.org/10.1101/2021.10.14.21265023; this version posted October 16, 2021. The copyright holder for this preprint (which was not certified by peer review) is the author/funder, who has granted medRxiv a license to display the preprint in It is made available under a CC-BY-NC-ND 4.0 International license .

in linkage disequilibrium and an enrichment for alleles that are rare in other populations, but can still be confidently imputed from genotyping data even in the rare and ultra-rare allele frequency spectrum ${ }^{7-9}$. Through combining imputed genotypes with detailed phenotypes ascertained through national registries, FG holds the promise to provide particular insights into the yet little examined allele frequency spectrum between 0.1 and $2 \%$ where both sequencing studies and GWAS have thus far remained largely underpowered to identify associations to disease. This spectrum includes many coding variants with moderate to large effect sizes that can help identify causal genes in GWAS loci, provide mechanistic insights into disease pathologies, and potentially bridge rare and common diseases.

Here, we have leveraged the combined power of UKB and FG to investigate how rare and lowfrequency variants in protein-coding regions of the genome contribute to the risk for human traits and diseases. Using data from a total of 653,219 individuals, we tested how $\sim 48,000$ coding variants identified in both biobanks through either whole-exome sequencing (WES) or genotype imputation associate with 744 distinct disease endpoints. Disease associations were compared against information from rare disease, biomarker and drug target resources and complemented by deep dives into distinct disease mechanisms of individual genes and coding variants. Our results showcase the benefits of combining large population cohorts to discover and replicate novel associations, explain disease mechanisms across a range of common and rare diseases, and shed light on a substantial gap in the allelic spectrum that neither genotyping nor sequencing studies have previously been able to address.

\section{Results}

91 An overview of the study design and basic demographics are provided in Extended Data

Figure 1 and Supplementary Table 1. In brief, we systematically harmonised disease 
medRxiv preprint doi: https://doi.org/10.1101/2021.10.14.21265023; this version posted October 16, 2021. The copyright holder for this preprint (which was not certified by peer review) is the author/funder, who has granted medRxiv a license to display the preprint in It is made available under a CC-BY-NC-ND 4.0 International license .

phenotypes across UKB and FG using Phecode and ICD10 mappings and retained 744 specific disease endpoints grouped into 580 disease clusters that span a broad range of diseases (Methods, Supplementary Table 2). Disease case counts relative to cohort size showed good correlations both, overall between UKB and FG (Spearman's $\rho=0.65, p<5.3 \times 10^{-90}$ ) and across distinct disease groups (Extended Data Figure 2).

\section{Coding-wide association analyses in 653,219 individuals across 744 disease}

\section{endpoints identify 975 genetic signals}

We performed coding-wide association studies (CWAS) across 744 disease endpoints over a mean of 48,189 (range: 25,309-89,993, Methods, Supplementary Table 2) post-QC coding variants across the allele frequency spectrum derived from whole-exome sequencing (WES) of 392,814 European ancestry individuals in UKB and meta-analysed these data with summary results from up to 260,405 individuals in FG (Methods, Supplementary Table 2).

We identified 975 associations (534 variants in 301 distinct regions across 148 disease clusters; 620 distinct region-disease cluster associations) meeting genome-wide significance $\left(p<5 \times 10^{-}\right.$ ${ }^{8}$ ), and 717 associations (378 variants in 231 distinct regions across 121 disease clusters; 445 distinct region-disease cluster associations) at a conservative (Bonferroni) multiple testing threshold of $p<2 \times 10^{-9}$ (correcting for the number of approximate independent tests) (Methods, Figure 1a, Supplementary Figure 1 (interactive), Supplementary Table 3). The distributions of coding variant annotation categories were largely similar for variants with at least one significant association $\left(p<5 \times 10^{-8}\right)$ relative to all variants tested, with missense variants showing a higher fraction of significant variants than in-frame indel or predicted loss-offunction (pLoF) variants (Extended Data Figure 3). Inflation was well controlled with a mean 
medRxiv preprint doi: https://doi.org/10.1101/2021.10.14.21265023; this version posted October 16, 2021. The copyright holder for this preprint (which was not certified by peer review) is the author/funder, who has granted medRxiv a license to display the preprint in It is made available under a CC-BY-NC-ND 4.0 International license .

118 Effect sizes were generally well aligned between UKB and FG (Spearman's $\rho=0.90, p<10^{-300}$,

119 Extended Data Figure 4b). MAFs of lead variants correlated well overall between UKB and

120 FG (Spearman's $\rho=0.97, p<10^{-300}$, Figure 1b), especially for variants with MAF $>1 \%$, yet as

121 expected $^{8}$ from genetic differences between Finns and non-Finnish Europeans (NFEs) was

122 reduced for variants with $\mathrm{MAF}<1 \%$ (Spearman's $\rho=0.32, p=0.023$ ).

124 Across all diseases, we found generally larger effect sizes for low frequency and rare variants (Figure 1c). 387 of the $975\left(39.7 \%\right.$ at $p<5 \times 10^{-8} ; 270 / 717(37.7 \%)$ at $\left.p<2 \times 10^{-9}\right)$ associations would not have been detected if analysed in UKB $\left(61.5 \%\right.$ at $p>5 \times 10^{-8} ; 60.1 \%$ at $\left.p>2 \times 10^{-9}\right)$ or FG $\left(59.6 \%\right.$ at $p>5 \times 10^{-8} ; 58.6 \%$ at $\left.p>2 \times 10^{-9}\right)$ alone. Association testing within UKB and FG individually would have yielded 318 and 479 associations respectively at $p<5 \times 10^{-8}$

(Supplementary Tables 4 and 5). Thus our combined approach utilizing both biobanks increased the number of significant findings by approximately 3- and 2-fold, respectively. Of the 318 and 479 significant sentinel variants in UKB and FG, $252(72.6 \%)$ and $258(53.9 \%)$ replicated at $p<0.05$ in FG and UKB respectively (Supplementary Tables 4 and 5), highlighting further the strength of our approach to yield results that are more robust through replication than would be findings derived from just a single biobank.

136 Our study benefits from population enrichment of rare alleles in Finns versus NFEs (and vice 137 versa) that increases the power for association discovery. Using a combination of theoretical analyses and empirical simulations, we show that by leveraging population-enriched variants we could increase inverse-variance weighted meta-analysis Z-scores and hence our ability to detect underlying associations. The gain in power from enriched alleles was present across a

141 range of rare MAFs (0.01-1\%), with the strongest power gain in the rare and ultra-rare minor 
medRxiv preprint doi: https://doi.org/10.1101/2021.10.14.21265023; this version posted October 16, 2021. The copyright holder for this preprint (which was not certified by peer review) is the author/funder, who has granted medRxiv a license to display the preprint in It is made available under a CC-BY-NC-ND 4.0 International license .

allele frequency (MAF) range of $0.01 \%$ to $0.25 \%$ (Figure 1d, Supplementary Information, Extended Data Figure 5, Supplementary Figure 2 (interactive)). Of the sentinel variants, we found 73 (33 in UKB, 40 in FG) to be enriched by $>2$-fold and 23 ( 8 in UKB, 15 in FG) by $>4$-fold relative to the respective other biobank (Figure 1b, Supplementary Table 6 ). The majority of highly population enriched variants are rare $(\mathrm{MAF}<1 \%)$ or low frequency (MAF $1-5 \%$ ), whereby 20 of 23 variants with $>4$-fold population enrichment (13 in FG and 7 in UKB) had MAF $<1 \%$ (Table 1, Supplementary Table 6).

We systematically cross-referenced our results with previously described GWAS associations (via GWAS Catalog ${ }^{10}$ and PhenoScanner ${ }^{11}$ ) and disease relevance as reported in ClinVar ${ }^{12}$ (Methods). In total, we found that 216 of 620 (34.8\%) distinct region-disease cluster associations had not previously been reported at $p<5 \times 10^{-8}\left(130 / 445[29.2 \%]\right.$ at $\left.p<2 \times 10^{-9}\right)$. Of the 216 distinct loci, $177\left(104 / 130\right.$ at $\left.p<2 \times 10^{-9}\right)$ were in genes not previously mapped to the respective diseases (Supplementary Table 3, Figure 1a, Supplementary Figure 1 (interactive)). Of the novel associations at GWAS significance $\left(p<5 \times 10^{-8}\right)$, roughly one third had $\mathrm{MAF}<5 \%$ in either UKB or FG and 15\% had MAF $<1 \%$ (Supplementary Table 3). Importantly, $17 \%$ of known (UKB; $19 \%$ in $\mathrm{FG}$ ), but $31 \%$ of novel (UKB; $28 \%$ in FG) associations had a MAF $<5 \%$. Correspondingly, $5 \%$ of known (UKB; $6 \%$ in FG) and $15 \%$ of novel (UKB; $10 \%$ in FG) associations had a $\mathrm{MAF}<1 \%$, highlighting the power gained through our approach especially in the low and rare allele frequency spectrum (Figure 1e,

\section{Supplementary Table 3).}

Mapping associations to genes, we found the majority of gene loci $\left(81.2 \%\right.$ at $p<5 \times 10^{-8}$, MHC region counted as one locus) to be associated with a single disease cluster (Extended Data Figure 6a). Thirteen loci were associated with $\geq 5$ trait clusters (at $p<5 \times 10^{-8}$ ), including well 
medRxiv preprint doi: https://doi.org/10.1101/2021.10.14.21265023; this version posted October 16, 2021. The copyright holder for this preprint (which was not certified by peer review) is the author/funder, who has granted medRxiv a license to display the preprint in It is made available under a CC-BY-NC-ND 4.0 International license .

(Figure 1a). For instance, in addition to a known association with breast cancer, we found variants in $C H E K 2$ as associated with the risk of colorectal and thyroid cancers, uterine

170 leiomyoma, benign meningeal tumours and ovarian cysts. Also, in addition to a known association with prostate hyperplasia, we found an $O D F 3$ missense variant (rs72878024) to be associated with risk of uterine leiomyoma, benign meningeal tumour, lipoma and polyps in the female genital tract (Supplementary Table 3).

Harnessing the added power of UKB and FG, we were able to detect GWAS associations for rare variants previously only annotated as causal for single-gene diseases, establishing a disease relevance for these variants at the population level. Of the 534 distinct variants with significant disease associations in our study $\left(p<5 \times 10^{-8}\right), 152$ had previously been linked to diseases in ClinVar. For 45 of these variants, the associated disease cluster matched with a previously reported phenotype in ClinVar. Notably, only six of these 45 variants (in GJB2, ABCC6, BRCA1, SERPINA1, FLG, and MYOC) had a previous annotation as either pathogenic or likely pathogenic (Supplementary Table 7), with 15 others annotated as benign. Of the novel trait cluster associations, 17 had been reported in ClinVar for the same/similar diseases, with 4 being classified as pathogenic/likely pathogenic and 13 classified either as benign or having "conflicting interpretation of pathogenicity" for the associated trait (Supplementary

Table 3, Supplementary Table 7). For instance, we found a rare missense variant annotated 187 as showing conflicting pathogenicity in ClinVar in $V W F$ (rs1800386:C; Tyr1584Cys; $188 \mathrm{MAF}=0.44 \%[\mathrm{UKB}], 0.47 \%[\mathrm{FG}])$ to be associated with the risk of von Willebrand disease ${ }^{12}$ $189\left(\log [\mathrm{OR}]=2.09, p=8.7 \times 10^{-9}\right)$; or a missense variant in SPINK1 (rs17107315:C; Asn34Ser; $\mathrm{MAF}=1.3 \%[\mathrm{UKB}], 1.6 \%$ [FG]) annotated as showing conflicting pathogenicity in ClinVar for 191 chronic pancreatitis to be associated with chronic pancreatitis $\operatorname{risk}^{12}\left(\log [\mathrm{OR}]=1.16, p=6.9 \times 10^{-}\right.$ 
medRxiv preprint doi: https://doi.org/10.1101/2021.10.14.21265023; this version posted October 16, 2021. The copyright holder for this preprint (which was not certified by peer review) is the author/funder, who has granted medRxiv a license to display the preprint in It is made available under a CC-BY-NC-ND 4.0 International license .

$\left.192{ }^{25}\right)$ and acute pancreatitis risk $\left(\log [\mathrm{OR}]=0.69, p=2.3 \times 10^{-18}\right)$. These examples highlight that 193 population-scale analyses like ours can help refine pathogenicity assignments through 194 contributing quantitative information on relative disease risks for variant carriers. Likewise, 17 195 of the 23 genes with highly population-enriched sentinel variants (Table 1) were OMIM listed 196 disease genes. Of these, 10 (CHEK2, DBH, SCL24A5, CFI, FLG, XPA, F10, BRCA1, SCN5A, 197 CACNA1D) showed associations with conditions identical or related to the respective 198 Mendelian disease, unveiling a relevance of the associated variants on the population level. For 199 instance, we found the missense variant rs77273740 in $D B H$ (enriched by $>50 \mathrm{x}$ in FG), a gene 200 associated with orthostatic hypotension, to be associated with reduced risk of hypertension $201\left(\log [\mathrm{OR}]=-0.19, p=1.3 \times 10^{-23}\right)$, whilst an in-frame deletion (rs1250342280) in CACNA1D 202 (enriched by $4.3 \mathrm{x}$ in UKB), a gene associated with primary aldosteronism, was associated with increased risk of hypertension $\left(\log [\mathrm{OR}]=0.19, p=2.0 \times 10^{-8}\right)$ (Table 1).

\section{Biomedical insights from coding variant associations}

206 We leveraged the coding variant associations identified in our study to generate biological insights for a range of distinct genes, pathways and diseases and in the following exemplify the broad utility of our resource through a set of selected use cases.

210 New roles of coagulation pathway proteins in conferring pulmonary embolism risk

211 We found known and novel associations with pulmonary embolism (PE) risk, including two

212 rare variant associations (average $\mathrm{MAF}<1 \%$ ) in genes encoding components of the coagulation

213 cascade at the convergent common pathway (Figure 2a). For instance, we discovered a rare

214 missense mutation in F10, enriched by 5-fold in FG (rs61753266:A; Glu142Lys; MAF=0.33\%

$215[\mathrm{UKB}], 1.85 \%[\mathrm{FG}])$, to be protective against $\mathrm{PE}\left(\log [\mathrm{OR}]=-0.44, p=2.9 \times 10^{-9}\right)$. This variant 216 has been associated with reduced plasma coagulation factor $\mathrm{X}\left(\right.$ beta $\left.=-1.12, p=2.0 \times 10^{-8}\right)$ and 
medRxiv preprint doi: https://doi.org/10.1101/2021.10.14.21265023; this version posted October 16, 2021. The copyright holder for this preprint (which was not certified by peer review) is the author/funder, who has granted medRxiv a license to display the preprint in It is made available under a CC-BY-NC-ND 4.0 International license .

217 factor $\mathrm{Xa}\left(\right.$ beta $\left.=-1.54, p=7.9 \times 10^{-15}\right)$ levels previously ${ }^{13}$, as well as clinical factor $\mathrm{X}$ deficiency ${ }^{14}$.

218 Deficiencies in coagulation factors, including factor X, are associated with increased bleeding

219 liability and reduced thrombotic risk. In a similar fashion, we found a previously reported 220 venous thromboembolism risk-reducing variant (rs4525:C; His865Arg; $\mathrm{MAF}=27.2 \%$ [UKB], $22.3 \%[\mathrm{FG}])$ in $F 5$ that is also protective for $\mathrm{PE}\left(\log [\mathrm{OR}]=-0.14, p=1.2 \times 10^{-15}\right)$ and associated with reduced plasma F5 levels ${ }^{15}$ (beta $=-0.25, p=6.0 \times 10^{-7}$ ). This variant acts opposite to the well-established risk promoting F5 Leiden missense mutation, which leads to increased resistance to activated protein $\mathrm{C}$ cleavage ${ }^{16}$ and thromboembolism liability, thus unravelling that coding variants in $F 5$ can have opposite effects on PE risk at the population level (Figure 2b). We performed Mendelian randomisation (MR) using rs4525 and rs61753266 as instruments to estimate the relative reduction in PE risk due to reduced F5 (beta MR $=0.57$, $\left.p=1.0 \times 10^{-15}\right)$ and F10 levels $\left(\mathrm{F} 10:\right.$ beta $_{\mathrm{MR}}=0.40, \mathrm{p}=2.9 \times 10^{-9} ; \mathrm{F} 10 \mathrm{a}:$ beta $\left._{\mathrm{MR}}=0.28, \mathrm{p}=2.9 \times 10^{-9}\right)$ respectively (Figure 2b). MR results support the expected clinical indication of factor $\mathrm{X}$ inhibitors in thromboembolic diseases and the hypothesis that developing drugs inhibiting factor $\mathrm{V}$ will also likely be beneficial for PE. We also found a rare variant in fibrinogen ( $F G B$ rs2227434:T; Pro100Ser; MAF=0.13\% [UKB], 0.15\% [FG], Figure 2a, Supplementary

Table 3) that associated with increased PE risk at nominal GWAS significance $(\log [\mathrm{OR}]=1.03$, $\left.p=1.5 \times 10^{-8}\right)$. Missense mutations in $F G B$ have previously been linked to both elevated and reduced fibrinogen levels through GWAS $^{17,18}$, as well as congenital afibrinogenemia ${ }^{19}$.

\section{Rare variant biomarker associations yield insights into disease mechanisms}

We interrogated the sentinel variants identified in this study for associations with 117 quantitative biomarkers spanning eight categories in UKB (Supplementary Table 8). At a multiple testing adjusted threshold of $p<1 \times 10^{-6}$, we found 108 of the biomarkers to be associated with at least one of 417 sentinel variants across 239 regions (Figure 3a, 
medRxiv preprint doi: https://doi.org/10.1101/2021.10.14.21265023; this version posted October 16, 2021. The copyright holder for this preprint (which was not certified by peer review) is the author/funder, who has granted medRxiv a license to display the preprint in It is made available under a CC-BY-NC-ND 4.0 International license .

242 Supplementary Table 9). 47 of the regions were associated with 5 or more biomarker categories (Extended Data Figure 6b, Supplementary Table 9), including pleiotropic disease loci such as $M H C, A P O E$, GCKR, SH2B3, FUT2, MC1R, ABCG5.

Many of the newly discovered associations with biomarkers are biologically plausible. For example, a low-frequency missense variant in $A D H 1 B$ (rs1229984:T; Arg48His; MAF=2.2\% [UKB], $0.5 \%[\mathrm{FG}])$ that is associated with increased enzymatic activity of alcohol dehydrogenase and reduced alcohol tolerance, is also associated with reduced risk of alcoholrelated disorders (alcoholic liver disease: $\log [\mathrm{OR}]=-1.08, p=1.5 \times 10^{-9}$; mental and behavioural disorders due to alcohol: $\log [\mathrm{OR}]=-0.82, p=1.2 \times 10^{-33}$ ) and increased risk of gout $\left(\log [\mathrm{OR}]=0.39, p=3.3 \times 10^{-10}\right)$. Notably, the alcohol dependence disorder-promoting $A D H 1 B$ allele $(\mathrm{C})$ is also associated with reduced IGF-1 (beta $\left.=-0.11, p=1.5 \times 10^{-51}\right)$ and vitamin D levels (beta=-0.049, $p=2.6 \times 10^{-10}$ ), increased levels of liver enzymes (alkaline phosphatase: beta $=0.087, p=3.1 \times 10^{-37}$; gamma-glutamyl transferase: beta $\left.=0.041, p=1.62 \times 10^{-9}\right)$ and total bilirubin ( $b$ eta $=0.031, p=5.1 \times 10^{-7}$ ), macrocytosis with increased mean corpuscular volume (beta $=0.047, p=4.2 \times 10^{-12}$ ) and mean corpuscular haemoglobin (beta $=0.048, p=1.4 \times 10^{-12}$ ), as well as reduced erythrocyte count (beta $=-0.034, p=3.2 \times 10^{-8}$ ). The gout risk reducing $\mathrm{C}$ allele is associated with reduced urate levels (beta $\left.=-0.061, p=1.4 \times 10^{-21}\right)$.

\section{A deletion in SLC34A1 is associated with multiple blood and urinary abnormalities}

262 Cross-referencing with biomarkers provided mechanistic insights into novel findings. For instance, we discovered a novel association between a low frequency in-frame deletion in SLC34A1 (rs1460573878, also known as rs876661296; MAF=2.6\% [UKB], 2.7\% [FG]; p.Val91_Ala97del) coding for the type II sodium phosphate cotransporter, NPT2a, which is expressed specifically in renal proximal tubular cells, to be associated with increased risk of 
medRxiv preprint doi: https://doi.org/10.1101/2021.10.14.21265023; this version posted October 16, 2021. The copyright holder for this preprint (which was not certified by peer review) is the author/funder, who has granted medRxiv a license to display the preprint in It is made available under a CC-BY-NC-ND 4.0 International license .

renal $\left(\log [\mathrm{OR}]=0.24, p=4.0 \times 10^{-9}\right)$ and urinary tract stones $\left(\log [\mathrm{OR}]=0.21, p=6.8 \times 10^{-9}\right)$. The deletion has previously been implicated in hypercalciuric renal stones ${ }^{20,21}$ and autosomal recessive idiopathic infantile hypercalcaemia 22 in family studies. The variant is also associated with increased serum calcium (beta $=0.047, p=5.4 \times 10^{-11}$ ) and reduced phosphate $($ beta $=-0.075$, $\left.p=3.3 \times 10^{-26}\right)$, consistent with a disrupted function/cell surface expression of the transporter ${ }^{22}$

(Figure 3b). We further find associations with increased levels of serum urate (beta $=0.048$, $p=4.5 \times 10^{-17}$ ), suggesting an increased risk also of uric acid stones. Additionally, we found associations with increased erythrocyte count (beta $=0.035, p=4.7 \times 10^{-10}$ ), haemoglobin concentration (beta $\left.=0.033, p=7.7 \times 10^{-10}\right)$ and haematocrit percentage $\left(\right.$ beta $\left.=0.036, p=9.9 \times 10^{-11}\right)$, suggesting increased renal-driven erythropoiesis (Figure 3b). Serum creatinine was not increased in carriers of the deletion (beta $=-0.07, p=3.6 \times 10^{-33}$ ), suggesting renal function is not adversely affected in deletion carriers. Amongst 11,114 renal/ureteric and 13,319 urinary tract stone cases, we identified 735 (renal/ureteric) and 863 (urinary tract) carriers of the deletion who may benefit from clinical interventions targeting NPT2a related pathways and monitoring for deranged biochemical and haematological biomarkers.

\section{A CHEK2 deletion is associated with blood cell counts and haematological malignancies}

A frameshift deletion in CHEK2 (rs555607708; MAF=0.64\% [FG], 0.24\% [UKB]) that increases breast cancer risk has been previously implicated also in myeloproliferative neoplasms through GWAS $^{23}$ and lymphoid leukaemia in a candidate variant study ${ }^{24}$.

287 Consistently, we found nominally significant associations with risks of both, myeloid $\left(\log [\mathrm{OR}]=1.52, p=9.5 \times 10^{-8}\right)$ and lymphoid $\left(\log [\mathrm{OR}]=1.38, p=3.1 \times 10^{-7}\right)$ leukaemia, but also multiple myeloma $\left(\log [\mathrm{OR}]=1.07, p=5.1 \times 10^{-5}\right)$ and non-Hodgkin lymphoma $(\log [\mathrm{OR}]=0.81$, $\left.p=4.7 \times 10^{-4}\right)$. Association of rs555607708 with clinical haematology traits showed statistically

291 significant associations with increased blood cell counts for both, myeloid (leukocytes, 
medRxiv preprint doi: https://doi.org/10.1101/2021.10.14.21265023; this version posted October 16, 2021. The copyright holder for this preprint (which was not certified by peer review) is the author/funder, who has granted medRxiv a license to display the preprint in It is made available under a CC-BY-NC-ND 4.0 International license .

neutrophils, platelets at $p<1 \times 10^{-6}$; monocyte and erythrocytes at $p<1 \times 10^{-3}$ ) and lymphoid (lymphocytes, $p=5.7 \times 10^{-17}$ ) lineages (Figure 3c). Furthermore, we found associations with increased mean platelet volume (MPV, $p=1.3 \times 10^{-16}$ ) and platelet distribution width (PDW, $\left.p=5.2 \times 10^{-13}\right)$, consistent with increased platelet activation and previous associations of MPV and PDW with chronic myeloid leukaemia ${ }^{25}$. We also found associations with decreased mean corpuscular haemoglobin $\left(p=7.8 \times 10^{-12}\right)$ and mean corpuscular volume $\left(p=5.3 \times 10^{-10}\right)$, suggesting predisposition to haematological cancers by loss-of CHEK2 function is accompanied by a microcytic red blood cell phenotype (Figure 3c).

\section{Coding variant associations inform drug discovery and development}

We cross-referenced genes with significant coding variant associations with drug targets using the therapeutic targets database ${ }^{26}$. We found 66 genes with trait cluster associations that are the targets of either approved drugs (26 genes) or drugs currently being tested in clinical trials (40 genes), among these, 14 in phase 3 trials (Supplementary Table 10). We found a statistical enrichment for significant genes in our study to also be approved drug targets (26/482; compared with a background of 569 approved targets/19,955 genes, $\mathrm{OR}=1.9, p=0.0024$ ), which is in line with previous estimates of a higher success rate for drug targets supported by genetics $^{27,28}$. Sensitivity analyses using more stringent association $p$-value thresholds further increased these probability estimates $\left(p=5 \times 10^{-9}[\mathrm{OR} 2.3, p=0.00070] ; p=5 \times 10^{-10}\right.$ [OR 2.5, $p=0.00037]$, supporting previous observations that the stronger the genetic association, the higher the likelihood of therapeutic success (Supplementary Table 11). In addition to providing further support for well-established drug target associations such as between PCSK9 loss-of-function and hypercholesterolaemia, or F10 loss-of-function and venous thromboembolism, we also found an association between a common missense variant (rs231775:G) in CTLA4 with increased risk of thyrotoxicosis $\left(\log [\mathrm{OR}]=0.12, p=8.5 \times 10^{-13}\right)$. 
medRxiv preprint doi: https://doi.org/10.1101/2021.10.14.21265023; this version posted October 16, 2021. The copyright holder for this preprint (which was not certified by peer review) is the author/funder, who has granted medRxiv a license to display the preprint in It is made available under a CC-BY-NC-ND 4.0 International license .

317 Since this variant is also a blood eQTL for decreased CTLA4 expression $^{29}$ (Z-score=-6.91,

$318 p=5.0 \times 10^{-12}$ ), the association between genetic CTLA4 reduction and thyroid dysfunction might

319 contribute to the adverse event of hyperthyroidism in cancer patients treated with CTLA4

320 inhibitors $^{30}$.

321

322 Genetics can inform drug discovery also on alternative indications for repurposing. For example, TYK2 inhibitors are being tested in clinical trials for various autoimmune and psoriatic diseases $^{31}$. Consistent with previous $\mathrm{GWAS}^{10}$, we found a missense variant in TYK2 (rs34536443:C) to be associated with reduced risk of rheumatoid arthritis and psoriatic diseases

(Supplementary Table 3). Our analyses establish this variant to also be associated with sarcoidosis $\left(\log [\mathrm{OR}]=-0.41, p=3.6 \times 10^{-8}\right)$, proposing sarcoidosis as a new indication for $T Y K 2$ inhibitors. Similarly, while the pleiotropy of CHEK2 provides support for exploring CHEK2 inhibitors against a broader spectrum of malignancies, our analyses also highlight a risk for potential haematological perturbations upon CHEK2 inhibitor treatment.

\section{Genetic insights into atrial fibrillation}

333 Atrial fibrillation (AF) GWAS have yielded a sizeable number of loci ${ }^{32,33}$. We chose AF to

334 exemplify how results from our study can further elucidate the genetics and biological basis of 335 one distinct human trait, with a particular emphasis on how our results might help to 336 disambiguate AF loci to causal genes and explain the functional significance of coding variant 337 associations. Indeed, we report several coding variant associations (Supplementary Table 3) 338 where prior GWAS ${ }^{32,33}$ had fallen short to resolve GWAS loci to coding genes and explain 339 disease mechanisms. 
medRxiv preprint doi: https://doi.org/10.1101/2021.10.14.21265023; this version posted October 16, 2021. The copyright holder for this preprint (which was not certified by peer review) is the author/funder, who has granted medRxiv a license to display the preprint in It is made available under a CC-BY-NC-ND 4.0 International license .

342 The AF GWAS sentinel variant rs72700114 is an intergenic variant located between METTL11B and LINC01142 $32-34$. Our study unveiled a low frequency missense variant in METTL11B (rs41272485:G; Ile127Met; MAF=3.9\% [UKB], 3.8\% [FG]) as associated with increased AF risk $\left(\log [\mathrm{OR}]=0.14, p=4.0 \times 10^{-11}\right)$. METTL11B is a $\mathrm{N}$-terminal monomethylase that methylates target proteins containing an N-terminal [Ala/Pro/Ser]-Pro-Lys motif ${ }^{35}$. The missense variant Ile127Met (SIFT=0, PolyPhen=1.0) falls within a conserved motif in the enzyme's S-adenosylmethionine/S-adenosyl-1-homocysteine ligand binding site ${ }^{36}$. METTL11B expression is enriched in heart and skeletal muscles with highest expression in heart muscle, in particular cardiomyocytes ${ }^{37,38}$. We scanned protein sequences for a presence of the [Ala/Pro/Ser]-Pro-Lys motif and elevated expression in cardiomyocytes (Methods,

Supplementary Table 12). We found statistically significant enrichment of genes encoding [Ala/Pro/Ser]-Pro-Lys motif containing proteins amongst genes with elevated expression in cardiomyocytes $\left(\mathrm{OR}=1.34,95 \% \mathrm{CI}=[1.16,1.54], p=3.2 \times 10^{-5}\right)$, many of which show Nterminal $[\mathrm{Ala} / \mathrm{Pro} / \mathrm{Ser}]-$ Pro-Lys motifs $\left(\mathrm{OR}=1.24,95 \% \mathrm{CI}=[1.06,1.44], p=5.6 \times 10^{-3}\right)$. This group included several well-established AF genes ${ }^{39}$ such as potassium channels $(K C N A 5$, KCNE4, KCNN3), sodium channels (SCN5A, SCN10A), NPPA, and TTN. Our data support METTL $11 B$ as the causal gene in this GWAS locus and a relevance for $\mathrm{N}$-terminal [Ala/Pro/Ser]-Pro-Lys methylation in cardiomyocytes for AF.

362 Within the SCN5A-SCN10A locus, we replicated a common missense variant in SCN10A 363 (rs6795970:A; Ala1073Val; MAF=40.0\% [UKB], 44.6\% [FG]) that was previously described to prolong cardiac conduction ${ }^{40}$. Additionally, we found associations with reduced AF risk $\left(\log [\mathrm{OR}]=-0.06, p=2.1 \times 10^{-12}\right)$, reduced pulse rate $\left(\mathrm{beta}=-0.02, p=4.8 \times 10^{-18}\right)$, and a suggestive 
medRxiv preprint doi: https://doi.org/10.1101/2021.10.14.21265023; this version posted October 16, 2021. The copyright holder for this preprint (which was not certified by peer review) is the author/funder, who has granted medRxiv a license to display the preprint in It is made available under a CC-BY-NC-ND 4.0 International license .

366

367

368

369

370

371

372

373

374

375

376

377

378

379

380

381

382

383

384

385

386

387

388

signal for increased risk of atrioventricular block $\left(\log [\mathrm{OR}]=0.10, p=1.9 \times 10^{-7}\right)$. On top of this, we discovered a rare, FG enriched missense variant (rs45620037:A; Thr220Ile; MAF=0.11\% [UKB], $0.47 \%$ [FG]; SIFT=0.03, PolyPhen=0.96) in $S C N 5 A$, encoding the cardiac sodium channel $\mathrm{Na}_{\mathrm{V}} 1.5$, as associated with decreased risk of $\mathrm{AF}\left(\log [\mathrm{OR}]=-0.65, p=1.3 \times 10^{-12}\right)$. The variant lies in the S4 voltage sensing segment of the first transmembrane domain of SCN5 $\mathrm{A}^{41}$ and leads to a substitution of the polar Thr to a non-polar Ile residue, most probably causing loss of function and electrophysiological changes ${ }^{42,43}$. The Thr220Ile variant has been associated with dilated cardiomyopathy ${ }^{44}$ and conduction defects including sick sinus syndrome and atrial standstill ${ }^{45}$ in family studies with bradycardic changes. Consistently, we found a nominal association with reduced pulse rate (beta $=-0.078, p=0.023$ ), suggesting that protective effects of the variant will be most beneficial for the common tachycardic form of AF through reducing pulse rate. Notably, our results identify both, $S C N 5 A$ and $S C N 10 A$ as likely causal genes at this AF locus.

Another AF GWAS locus is tagged by the common intergenic sentinel variant rs 74022964 between HCN4 and REC114 ${ }^{32,33}$. We identified a rare, FG enriched variant in $H C N 4$ (rs151004999:T; Asp364Asn; MAF=0.045\% [UKB], 0.17\% [FG]; SIFT=0.05, PolyPhen=0.41) as associated with increased AF risk $\left(\log [\mathrm{OR}]=0.72, p=2.8 \times 10^{-8}\right)$. HCN4 is a hyperpolarization-activated ion channel contributing to cardiac pacemaker (funny) currents ( $\mathrm{I}_{\mathrm{f}}$ ). Mutations in $H C N 4$ have been associated with familial bradycardia (also known as sick sinus syndrome 2) and Brugada syndrome 8 in family studies ${ }^{46}$. Consistently, in our study we also found an association with decreased heart rate (beta $\left.=-0.49, p=3.8 \times 10^{-21}\right)$. 
medRxiv preprint doi: https://doi.org/10.1101/2021.10.14.21265023; this version posted October 16, 2021. The copyright holder for this preprint (which was not certified by peer review) is the author/funder, who has granted medRxiv a license to display the preprint in It is made available under a CC-BY-NC-ND 4.0 International license .

390 To further evaluate the hypothesis that distinct genetic mechanisms underlying AF risk inversely modulate pulse rate, we applied clustered Mendelian randomization (MR-Clust) ${ }^{47}$ with a slight modification to the mixture-model to better accommodate rare-variants. Specifically, we related expectation maximization clustering of AF associated variants with

394 homogenous directional effects on pulse rate (Methods). Among the AF sentinel variants from our coding variant association analyses, we found the two above described clusters of variants in SCN10A (rs6795970) and HCN4 (rs151004999), suggestive of two genetic components of AF that can increase and decrease pulse rate, respectively (Figure 4a, left). Identifying components of AF with diverging directionality on pulse rate is not surprising given clinically AF can be driven by both tachycardia and bradycardia through distinct mechanisms ${ }^{48}$. As sensitivity analyses, we used sentinel variants from a recent $\mathrm{AF}$ GWAS ${ }^{32}$ where the candidate gene sets overlapped those in our study and found concordant patterns (Figure 4a, left-middle,

Supplementary Table 13). We also included all sentinel variants in the AF GWAS $\operatorname{loci}^{32}$ and Conversely, as expected, permuting pulse rate led to no clustering and null associations between $\mathrm{AF}$ and pulse (Figure 4a, right). Expectedly, within the AF GWAS loci ${ }^{32}$ the two rare missense alleles in HCN4 (rs151004999:T, $\log [\mathrm{OR}]=0.72)$ and SCN5A (rs45620037:A, $\log [\mathrm{OR}]=-0.65)$ identified in our study had much larger effect sizes on AF risk than the respective non-coding sentinel GWAS variants (rs74022964:T [HCN4 locus], $\log [\mathrm{OR}]=0.12$; rs6790396:C [SCN5A, SCN10A locus], $\log [\mathrm{OR}]=-0.058)$ (Figure 4a).

PITX2c Pro41Ser increases AF risk through a gain-of-function mechanism

412 Lastly, we found a rare missense variant in PITX2 as associated with increased risk of AF $413\left(\log [\mathrm{OR}]=0.38, p=1.1 \times 10^{-9}\right)$. This variant is enriched nearly 50 -fold in FG (rs143452464:A; 
medRxiv preprint doi: https://doi.org/10.1101/2021.10.14.21265023; this version posted October 16, 2021. The copyright holder for this preprint (which was not certified by peer review) is the author/funder, who has granted medRxiv a license to display the preprint in It is made available under a CC-BY-NC-ND 4.0 International license .

414 Pro41Ser; MAF=0.023\% [UKB], 1.1\% [FG]) and was independently identified in a French

415 family with AF (Supplementary Information, Supplementary Figure Pro41Ser 1), whilst

416 GWAS had linked intergenic variants between PITX2 and FAM241A to AF risk. PITX2 is a

417 bicoid type homeobox transcription factor previously assumed to play a role in cardiac rhythm

418 control $^{49}$. The Pro41Ser variant lies in the N-terminal domain that is only present in the PITX2c

419 isoform expressed in cardiac muscle (Figure 4b left). We performed reporter assays comparing

420 the ability of Xpress-PITX2c constructs to transactivate a luciferase reporter plasmid

421 containing a putative PITX2c binding element (Supplementary Information). A construct

422 containing the Pro41Ser variant showed a $\sim 2.4$-fold higher activation of the reporter than the

423 wild-type construct ( $p=0.006$, Figure $4 \mathbf{b}$ middle). This effect was abrogated upon deletion of the putative PITX2c binding site (Figure 4b middle; see also Supplementary Information,

Supplementary Figure Pro41Ser 2 and Supplementary Figure Pro41Ser 3). In cultured cardiac muscle HL-1 cells, Pro41Ser increased the transcription of several presumed PITX2c target genes, specifically GJA1 (Cx40,1.76-fold, $p=0.012)$, GJA5 (Cx43, 1.85-fold, $p=0.005)$ and $K C N H 2$ (1.81-fold, $p=0.009)$, while the transcription of other selected genes with putative roles in AF was not substantially altered (Figure 4b right, Supplementary Table 14, see also

Supplementary Information). Together, these results are consistent with a putative gain-offunction mechanism of Pro41Ser on PITX2c transactivation potential and AF risk.

\section{Discussion}

434 Here, we have conducted the to date largest association study of protein-coding genetic variants against hundreds of disease endpoints ascertained from two massive population biobanks, UK

436 Biobank and FinnGen. We report novel disease associations, most notably in the rare and low 437 allelic frequency spectrum, replicate and assign putative causalities to many previously reported GWAS associations, and leverage the insights gained to elucidate disease 
medRxiv preprint doi: https://doi.org/10.1101/2021.10.14.21265023; this version posted October 16, 2021. The copyright holder for this preprint (which was not certified by peer review) is the author/funder, who has granted medRxiv a license to display the preprint in It is made available under a CC-BY-NC-ND 4.0 International license .

mechanisms. In addition to a substantial gain in power over previous studies, our analyses benefit from replication between two population cohorts, increasing the robustness of our findings and setting the stage for future similar studies in ethnically more diverse populations.

Importantly, our study identifies both, pathogenic variants residing in monogenic disease genes to impact the risk for related complex conditions, as well as new, likely causal sentinel variants within GWAS loci in genes with known and novel biological roles in the respective GWAS trait. With this, our study is one of the first to help bridge the gap between common and rare disease genetics across a broad range of conditions and provides support for the hypothesis that the genetic architecture of many diseases is continuous ${ }^{1}$. As reflected in a recent schizophrenia study ${ }^{50}$, GWAS tend to identify association signals primarily for variants with MAF $>2 \%$, while most variants identified through exome sequencing are ultra-rare $(\mathrm{MAF}<0.01 \%)$. Of the 975 associations identified in our study, 145 are driven by unique variants in the yet little interrogated rare and low allelic frequency spectrum that is hypothesized to contribute substantially to the "missing heritability" of many human diseases ${ }^{51}$.

Our approach benefits considerably from the Finnish genetic background where, consistent with previous observations $s^{6-8}$, certain alleles are stochastically enriched to unusually high allele frequencies, at times exceeding population frequencies in the UK Biobank by $>50$-fold (such as for instance the PITX2-Pro41Ser variant). Our theoretical and empirical results suggest the increasing utility of enriched variants for identifying associations quantitatively towards lower allelic frequencies. Notably, we identify the most prominent relative power gain in the rarest variant frequency spectrum, highlighting a role for sequencing studies and integrating additional population cohorts with enriched variants for identifying novel disease associations at scale. In our study, we identify several alleles with comparatively high effect sizes and a 
medRxiv preprint doi: https://doi.org/10.1101/2021.10.14.21265023; this version posted October 16, 2021. The copyright holder for this preprint (which was not certified by peer review) is the author/funder, who has granted medRxiv a license to display the preprint in It is made available under a CC-BY-NC-ND 4.0 International license .

prevalence in the population that warrants follow-up, both experimentally as well as potentially directly in clinical settings to help improve disease outcomes. For instance, our data propose that $6.5 \%$ of $\mathrm{UKB}$ and FG participants with kidney or urinary tract stones, conditions debilitating $>15 \%$ of men and $5 \%$ of women by 70 years of age $e^{52}$, carry a deletion in SLC34A1. Monitoring patients for the clinical biomarkers identified here as associated with this deletion might help to differentiate aetiologies and guide individualized treatments. Likewise, coding variant associations identified in our study may serve as an attractive source to generate hypotheses for drug discovery programs. Our results support previous studies ${ }^{27,28}$ that drug targets supported by human genetics have an increased likelihood of success, which can be considered particularly high when the genetic effect on a drug target closely mimics that of a pharmacological intervention ${ }^{53}$.

We demonstrate the broad utility of our results through numerous examples. For instance, in the case of AF we show how coding variants can help disambiguate GWAS loci to likely causal genes and in some cases predict specific changes in a protein's function; how integration of genetics with intermediate traits (such as slow versus fast heart rate) can unravel different biological mechanisms underlying a disease entity; or how a putative function of sentinel coding variants can be further validated through experiments. Our examples highlight that the step from association to biological insight may be considerably shorter for coding variant association studies than it has traditionally been for GWAS.

The results of our study foreshadow the discovery of many additional coding and non-coding associations from cross-biobank analyses at even larger sample sizes. With the continued growth of population biobanks with comprehensive health data also in non-European populations, the emergence of more and more cost-effective technologies for sequencing and 
medRxiv preprint doi: https://doi.org/10.1101/2021.10.14.21265023; this version posted October 16, 2021. The copyright holder for this preprint (which was not certified by peer review) is the author/funder, who has granted medRxiv a license to display the preprint in It is made available under a CC-BY-NC-ND 4.0 International license.

489 genotyping, and computational advances to analyse genetic and non-genetic data at scale,

490 future studies will be able to assess the genetic contribution to health and disease at even finer 491 resolution.

492 
medRxiv preprint doi: https://doi.org/10.1101/2021.10.14.21265023; this version posted October 16, 2021. The copyright holder for this preprint (which was not certified by peer review) is the author/funder, who has granted medRxiv a license to display the preprint in It is made available under a CC-BY-NC-ND 4.0 International license .

\section{Methods}

\section{Samples and participants}

495 UK biobank (UKB) is a UK population study of approximately 500,000 participants aged 40-

49669 years at recruitment ${ }^{2}$. Participant data include genomic, electronic health record linkage,

497 blood, urine and infection biomarkers, physical and anthropometric measurements, imaging

498 data and various other intermediate phenotypes that are constantly being updated. Further

499 details are available at https://biobank.ndph.ox.ac.uk/showcase/. Analyses in this study were

500 conducted under UK Biobank Approved Project number 26041.

501

502 FinnGen (FG) is a public-private partnership project combining electronic health record and

503 registry data from six regional and three Finnish biobanks. Participant data include genomics

504 and health records linked to disease endpoints. Further details are available at

505 https://www.finngen.fi/. More details on FG and ethics protocols are provided in

506 Supplementary Information. We used data from FG participants with completed genetic

507 measurements (R5 data release) and imputation (R6 data release). FinnGen participants

508 provided informed consent for biobank research. Recruitment protocols followed the biobank

509 protocols approved by Fimea, the National Supervisory Authority for Welfare and Health. The

510 Coordinating Ethics Committee of the Hospital District of Helsinki and Uusimaa (HUS)

511 approved the FinnGen study protocol Nr HUS/990/2017. The FinnGen study is approved by

512 Finnish Institute for Health and Welfare.

\section{Disease phenotypes}

515 FG phenotypes were automatically mapped to those used in the Pan UKBB

516 (https://pan.ukbb.broadinstitute.org/) project. Pan UKBB phenotypes are a combination of 
medRxiv preprint doi: https://doi.org/10.1101/2021.10.14.21265023; this version posted October 16, 2021. The copyright holder for this preprint (which was not certified by peer review) is the author/funder, who has granted medRxiv a license to display the preprint in It is made available under a CC-BY-NC-ND 4.0 International license .

517 Phecodes $^{54}$ and ICD10 codes. Phecodes were translated to ICD10

518 (https://phewascatalog.org/phecodes_icd10, v.2.1) and mapping was based on ICD-10

519 definitions for FG endpoints obtained from cause of death, hospital discharge and cancer

520 registries. For disease definition consistency, we reproduced the same Phecode maps using the

521 same ICD-10 definitions in UKB. In particular, we expertly curated 15 neurological

522 phenotypes using ICD10 codes. We retained phenotypes where the similarity score (Jaccard

523 index: $\left.\mathrm{ICD} 10_{\mathrm{FG}} \cap \mathrm{ICD} 10_{\mathrm{UKB}} / \mathrm{ICD} 10_{\mathrm{FG}} \cup \mathrm{ICD} 10_{\mathrm{UKB}}\right)$ was $>0.7$ and additionally excluded

524 spontaneous deliveries and abortions.

525

526 Phecodes and ICD10 coded phenotypes were first mapped to unified disease names and disease

527 groups using mappings from Phecode, "PheWAS" and "icd" R packages followed by manual

528 curation of unmapped traits and diseases groups, mismatched and duplicate entries. Disease

529 endpoints were mapped to Experimental Factor Ontology (EFO) terms using mappings from

530 EMBL-EBI and Open Targets based on exact disease entry matches followed by manual

531 curation of unmapped traits.

532

533 Disease trait clusters were determined through first calculating the phenotypic similarity via

534 the cosine similarity, then determining clusters via hierarchical clustering on the distance

535 matrix (1-similarity) using the Ward algorithm and cutting the hierarchical tree, after inspection, 536 at height 0.8 to provide the most semantically meaningful clusters.

\section{Genetic data processing}

\section{UKB genetic QC}

540 UKB genotyping and imputation were performed as described previously ${ }^{2}$. WES data for UKB participants were generated at the Regeneron Genetics Center (RGC) as part of a collaboration 
medRxiv preprint doi: https://doi.org/10.1101/2021.10.14.21265023; this version posted October 16, 2021. The copyright holder for this preprint (which was not certified by peer review) is the author/funder, who has granted medRxiv a license to display the preprint in It is made available under a CC-BY-NC-ND 4.0 International license .

542 between AbbVie, Alnylam Pharmaceuticals, AstraZeneca, Biogen, Bristol-Myers Squibb,

543 Pfizer, Regeneron and Takeda with the UK Biobank. WES data were processed using the RGC

544 SBP pipeline as described in ${ }^{3,55}$. RGC generated a QC-passing "Goldilocks" set of genetic

545 variants from a total of 454,803 sequenced UK Biobank participants for analysis. Additional

546 QC were performed prior to association analyses as detailed below.

FG genetic QC

549 Samples were genotyped with Illumina (Illumina Inc., San Diego, CA, USA) and Affymetrix 550 arrays (Thermo Fisher Scientific, Santa Clara, CA, USA). Genotype calls were made with

551 GenCall and zCall algorithms for Illumina and AxiomGT1 algorithm for Affymetrix data.

552 Sample, genotyping as well as imputation procedures and QC are detailed in Supplementary

Information.

\section{Coding variant selection}

556 GnomAD v.2.0 variant annotations were used for FinnGen variants ${ }^{56}$. The following gnomAD annotation categories are included: predicted loss-of-function (pLoF), low-confidence loss-offunction (LC), in-frame indel, missense, start lost, stop lost, stop gained. Variants have been

filtered to imputation INFO score $>0.6$. Additional variant annotations were performed using variant effect predictor (VEP) ${ }^{57}$ with SIFT and PolyPhen scores averaged across the canonical annotations.

\section{Disease endpoint association analyses}

564 For optimized meta-analyses with FG, analyses in UKB were performed in the subset of 565 exome-sequence UKB participants with white European ancestry for consistency with FG $566(\mathrm{n}=392,814)$. We used REGENIE v1.0.6.7 for association analyses via a two-step procedure as 
medRxiv preprint doi: https://doi.org/10.1101/2021.10.14.21265023; this version posted October 16, 2021. The copyright holder for this preprint (which was not certified by peer review) is the author/funder, who has granted medRxiv a license to display the preprint in It is made available under a CC-BY-NC-ND 4.0 International license .

detailed in ${ }^{58}$. In brief, the first step fits a whole genome regression model for individual trait predictions based on genetic data using the leave one chromosome out (LOCO) scheme. We used a set of high-quality genotyped variants: minor allele frequency (MAF) $>5 \%$, minor allele count (MAC) $>100$, genotyping rate $>99 \%$, Hardy-Weinberg equilibrium (HWE) test $p>10^{-15}$, $<5 \%$ missingness and linkage-disequilibrium (LD) pruning (1000 variant windows, 100 sliding windows and $\left.r^{2}<0.8\right)$. Traits where the step 1 regression failed to converge due to case imbalances were subsequently excluded from subsequent analyses. The LOCO phenotypic predictions were used as offsets in step 2 which performs variant association analyses using the approximate Firth regression detailed in ${ }^{58}$ when the $p$-value from the standard logistic regression score test is below 0.01. Standard errors (SEs) were computed from the effect size estimate and the likelihood ratio test p-value. To avoid issues related to severe case imbalance and extremely rare variants, we limited association test to phenotypes with $>100$ cases and for variants with $\mathrm{MAC} \geq 5$ in total samples and $\mathrm{MAC} \geq 3$ in cases and controls. The number of variants used for analyses varies for different diseases as a result of the MAC cut-off for different disease prevalence. The association models in both steps also included the following covariates: age, age ${ }^{2}$, sex, age* sex, age ${ }^{2 *}$ sex, first 10 genetic principle components (PCs).

Association analyses in FG were performed using mixed model logistic regression method SAIGE v0.3959. Age, sex, 10 PCs and genotyping batches were used as covariates. For null model computation for each endpoint each genotyping batch was included as a covariate for an endpoint if there were at least 10 cases and 10 controls in that batch to avoid convergence issues. One genotyping batch need be excluded from covariates to not have them saturated. We excluded Thermo Fisher batch 16 as it was not enriched for any particular endpoints. For calculating the genetic relationship matrix, only variants imputed with an INFO score $>0.95$ in all batches were used. Variants with $>3 \%$ missing genotypes were excluded as well as variants 
medRxiv preprint doi: https://doi.org/10.1101/2021.10.14.21265023; this version posted October 16, 2021. The copyright holder for this preprint (which was not certified by peer review) is the author/funder, who has granted medRxiv a license to display the preprint in It is made available under a CC-BY-NC-ND 4.0 International license .

592

593

594

595

596

597

598

599

600

601

602

603

604

605

606

607

608

609

610

611

612

613

614 We defined independent trait associations through LD-based $\left(\mathrm{r}^{2}=0.1\right)$ clumping $\pm 500 \mathrm{~Kb}$

615 around the lead variants using PLINK ${ }^{61}$, excluding the HLA region (chr6:25.5-34.0Mb) which

616

with $\mathrm{MAF}<1 \%$. The remaining variants were $\mathrm{LD}$ pruned with a $1 \mathrm{Mb}$ window and $\mathrm{r}^{2}$ threshold of 0.1 . This resulted in a set of 59,037 well-imputed not rare variants for GRM calculation. SAIGE options for null computation were: "LOCO=false, numMarkers=30, traceCV cutoff $=0.0025$, ratioCV cutoff $=0.001$ '. Association tests were performed phenotypes with case counts $>100$ and for variants with minimum allele count of 3 and imputation info $>0.6$ were used.

We additionally performed sex-specific associations for a subset of gender-specific diseases (60 female diseases and in 50 disease clusters, 14 male diseases and in 13 disease clusters) in both FG and UKB using the same approach without inclusion of sex-related covariates

\section{(Supplementary Table 2)}

We performed fixed-effect inverse-variance meta-analysis combining summary effect sizes and standard errors for overlapping variants with matched alleles across FG and UKB using METAL $^{60}$.

\section{Definition and refinement of significant regions}

To define significance, we used a combination of (1) multiple testing corrected threshold of $p<2 \times 10^{-9}, 0.05 /\left(\sim 26.8 \times 10^{6}\right)$ [sum (mean number of variants tested per disease cluster)], to account for the fact that some traits are highly correlated disease subtypes, (2) concordant direction of effect between UKB and FG associations, and (3) $p<0.05$ in both UKB and FG.

\footnotetext{
is treated as one region due to complex and extensive LD patterns. We then merged overlapping
} 
medRxiv preprint doi: https://doi.org/10.1101/2021.10.14.21265023; this version posted October 16, 2021. The copyright holder for this preprint (which was not certified by peer review) is the author/funder, who has granted medRxiv a license to display the preprint in It is made available under a CC-BY-NC-ND 4.0 International license .

617 independent regions $( \pm 500 \mathrm{~Kb})$ and further restricted each independent variant $\left(\mathrm{r}^{2}=0.1\right)$ to the

618 most significant sentinel variant for each unique gene. For defining region associations across

619 traits, we merged overlapping independent regions for each individual trait.

620

\section{Cross reference with known genetic associations}

622 We cross-referenced the sentinel variants and their proxies $\left(r^{2}>0.2\right)$ for significant associations $623\left(p<5 \times 10^{-8}\right)$ of mapped Experimental Factor Ontology (EFO) terms and their descendants in 624 GWAS Catalog ${ }^{10}$ and PhenoScanner ${ }^{11}$. To be more conservative with reporting of novel 625 associations, we also considered whether the most-severe associated gene in our analyses were reported in GWAS Catalog and PhenoScanner. In addition, we also queried our sentinel variants in ClinVar ${ }^{12}$ to define known associations with rarer genetic diseases and further manually curated novel associations for previous genome-wide significant $\left(p<5 \times 10^{-8}\right)$ associations.

630

\section{Biomarker associations of lead variants}

632 For the lead sentinel variants, we performed association analyses using the two-step REGENIE approach described above with 117 biomarkers including anthropometric traits, physical measurements, clinical haematology measurements, blood and urine biomarkers available in UKB (detailed in Supplementary Table 8).

\section{Drug target mapping and enrichment}

638 We mapped the annotated gene for each sentinel variant to drugs using the therapeutic target 639 database (TTD) ${ }^{26}$. We retained only drugs which have been approved or are in clinical trial 640 stages. For enrichment analysis of approved drugs with genetic associations, we used Fisher's exact test on the proportion of significant genes targeted by approved drug against a 
medRxiv preprint doi: https://doi.org/10.1101/2021.10.14.21265023; this version posted October 16, 2021. The copyright holder for this preprint (which was not certified by peer review) is the author/funder, who has granted medRxiv a license to display the preprint in It is made available under a CC-BY-NC-ND 4.0 International license .

642 background of all approved drugs in $\operatorname{TTD}^{26}(n=595)$ and 20,437 protein coding genes from

643 Ensembl annotations ${ }^{62}$.

644

645 Mendelian randomization (MR) analyses

$646 \quad$ F5 and F10 effect on pulmonary embolism (PE) risk

647 The missense variants rs4525 and rs61753266 in F5 and F10 genes were taken as genetic 648 instruments for MR analyses. To assess potential that each factor level is causally associated 649 with PE we employed two-sample MR using summary statistics, with effect of the variants on 650 their respective factor levels obtained from previous large scale (protein quantitative trait loci) 651 pQTL studies ${ }^{13,15}$. Let $\beta_{X Y}$ denote the estimated causal effect of a factor level on PE risk and $\beta_{X}$, $652 \beta_{Y}$ be the genetic association with a factor level (FV, FX or FXa) and PE risk respectively. 653 Then, the MR ratio-estimate of $\beta_{X Y}$ is given by:

$$
\beta_{X Y}=\frac{\beta_{Y}}{\beta_{X}}
$$

where the corresponding standard error $\operatorname{se}\left(\beta_{X Y}\right)$, computed to leading order, is:

$$
\operatorname{se}\left(\beta_{X Y}\right)=\frac{\operatorname{se}\left(\beta_{Y}\right)}{\left|\beta_{X}\right|}
$$

\section{Clustered MR}

659 To assess evidence of several distinct causal mechanisms by which atrial fibrillation (AF) may

660 influence pulse rate (PR) we used MR-Clust ${ }^{47}$. In brief, MR-Clust is a purpose-built clustering 661 algorithm for use in univariate MR analyses. It extends the typical MR assumption that a risk 662 factor can influence an outcome via a single causal mechanism ${ }^{63}$ to a framework that allows 663 one or more mechanisms to be detected. When a risk-factor affects an outcome via several 664 mechanisms, the set of two-stage ratio-estimates can be divided into clusters, such that variants 665 within each cluster have similar ratio-estimates. As shown in ${ }^{47}$, two or more variants are 
medRxiv preprint doi: https://doi.org/10.1101/2021.10.14.21265023; this version posted October 16, 2021. The copyright holder for this preprint (which was not certified by peer review) is the author/funder, who has granted medRxiv a license to display the preprint in It is made available under a CC-BY-NC-ND 4.0 International license

666

667 pathway. Moreover, the estimated causal effect from a cluster is proportional to the total causal

668 effect of the mechanism on the outcome. We included variants within clusters where the

669 probability of inclusion $>0.7$. We used MR-Clust algorithm allowing for singletons/outlier

670 variants to be identified as their own "clusters" to reflect the large but biologically plausible

671 effect sizes seen with rare and low frequency variants.

672

673

674

675 function on UniProt ${ }^{64}$, filtering for reviewed Swiss-Prot proteins and proteins listed in Human

676 Protein Atlas $(\text { HPA })^{38} \quad(n=7,656)$. We obtained genes with elevated expression in

677 cardiomyocytes $(\mathrm{n}=880)$ from HPA based on the criteria: "cell_type_category_rna:

678 cardiomyocytes; cell type enriched, group enriched, cell type enhanced" as defined by HPA in

679 (https://www.proteinatlas.org/humanproteome/celltype/Muscle+cells\#cardiomyocytes

680 [accessed 20/03/2021]) with filtering for those with valid UniProt IDs (Swiss-Prot, n=863).

681 Enrichment test was performed using Fisher's exact test. Additionally, we performed 682

683 half of the protein $(n=4,786)$.

684 
medRxiv preprint doi: https://doi.org/10.1101/2021.10.14.21265023; this version posted October 16, 2021. The copyright holder for this preprint (which was not certified by peer review) is the author/funder, who has granted medRxiv a license to display the preprint in It is made available under a CC-BY-NC-ND 4.0 International license .

\section{Acknowledgements}

686 We thank all the participants, contributors and researchers of UK Biobank and FinnGen (and

687 its participating biobanks) for making data available for this study. We thank the UK Biobank

688 Exome Sequencing Consortium (AbbVie, Alnylam Pharmaceuticals, AstraZeneca, Biogen,

689 Bristol-Myers Squibb, Pfizer, Regeneron and Takeda) for generation the whole exome

690 sequencing data and Regeneron Genetics Centre for initial quality control of the exome

691 sequencing data. The FinnGen project is funded by two grants from Business Finland (HUS

$6924685 / 31 / 2016$ and UH 4386/31/2016) and the following industry partners: AbbVie Inc.,

693 AstraZeneca UK Ltd, Biogen MA Inc., Celgene Corporation, Celgene International II Sàrl,

694 Genentech Inc., Merck Sharp \& Dohme Corp, Pfizer Inc., GlaxoSmithKline Intellectual

695 Property Development Ltd., Sanofi US Services Inc., Maze Therapeutics Inc., Janssen Biotech

696 Inc, and Novartis AG. We thank Susanna Lemmelä for her contribution to FinnGen data

697 curation. We further thank Yi-Qing Yang, Tim Footz, Michael Walter, Amelia Aránega,

698 Francisco Hernández-Torres, Elodie Morel and Gilles Millat for their contributions to the

699 functional characterisation of PITX2c. PITX2 functional work was supported in part by grants

700 from the National Natural Science Fund of China (81070153), the Personnel Development

701 Foundation of Shanghai, China (2010019), and the Key Program of Basic Research of

702 Shanghai, China (10JC1414002), and by the Canadian Institutes of Health Research (grants

703 MOP-111072 and MOP-130373 to Mohamed Chahine). Asma Mechakra was supported by a 704 bursary of the French Ministry of Research and Technology (MRT).

705

706 Author contributions

707 Conceptualization and experimental design: B.B.S., H.R.; methodology: B.B.S., H.R., C.N.F., 708 C.C., M.J.D.; analysis: B.B.S., M.I.K., C.N.F., A.M., C.C., E.M., J.B.W., Biogen Biobank 
medRxiv preprint doi: https://doi.org/10.1101/2021.10.14.21265023; this version posted October 16, 2021. The copyright holder for this preprint (which was not certified by peer review) is the author/funder, who has granted medRxiv a license to display the preprint in It is made available under a CC-BY-NC-ND 4.0 International license.

709 Team; experimental work: A.M., G.C., M.C., P.C.; FinnGen protocols and analysis: M.I.K.,

710 A.P., M.J.D., FinnGen; writing: B.B.S., H.R.; all authors critically reviewed the manuscript.

711

712 Correspondence

713 Correspondence and requests for materials should be addressed to B.B.S.

714 (bbsun92@outlook.com) or H.R. (heiko.runz.@gmail.com).

715 
medRxiv preprint doi: https://doi.org/10.1101/2021.10.14.21265023; this version posted October 16, 2021. The copyright holder for this preprint (which was not certified by peer review) is the author/funder, who has granted medRxiv a license to display the preprint in It is made available under a CC-BY-NC-ND 4.0 International license.

\section{Figures and Tables}

717 Figure 1. Coding genetic associations with disease. Manhattan plot for novel associations and 718 allelic enrichment surface plots are provided as Interactive Supplementary Figures 1 and 2. (a) 719 Summary of sentinel variant associations. Size of the point is proportional to effect size. $-\log _{10}(p)$ capped at $-\log _{10}\left(10^{-50}\right)$. Labels highlight pleiotropic associations ( $\geq 5$ trait clusters). Colours indicate disease groups. Shape indicate novel/known (grey circles) associations. Dotted horizontal lines: $\log _{10}\left(2 \times 10^{-9}\right)$ [brown] and $-\log _{10}\left(5 \times 10^{-8}\right)$ [grey]. (b). Comparison of sentinel variant MAF between UKB and FG. (c) Effect size against MAF of sentinel variants. Dashed lines indicate MAF of $0.1 \%$ (left) and $1 \%$ (right). (d) Surface plot of effects of cohort specific allele enrichment on inverse variant weighted meta-analysis z-scores (IVW uplift) across MAFs (up to MAF 1\%). Uplift is defined as the ratio of meta-analysed IVW Z-score to the Z-score of an individual study (details in Supplementary Information). (e) Density plot of MAF for sentinel variants for known vs novel associations.

a

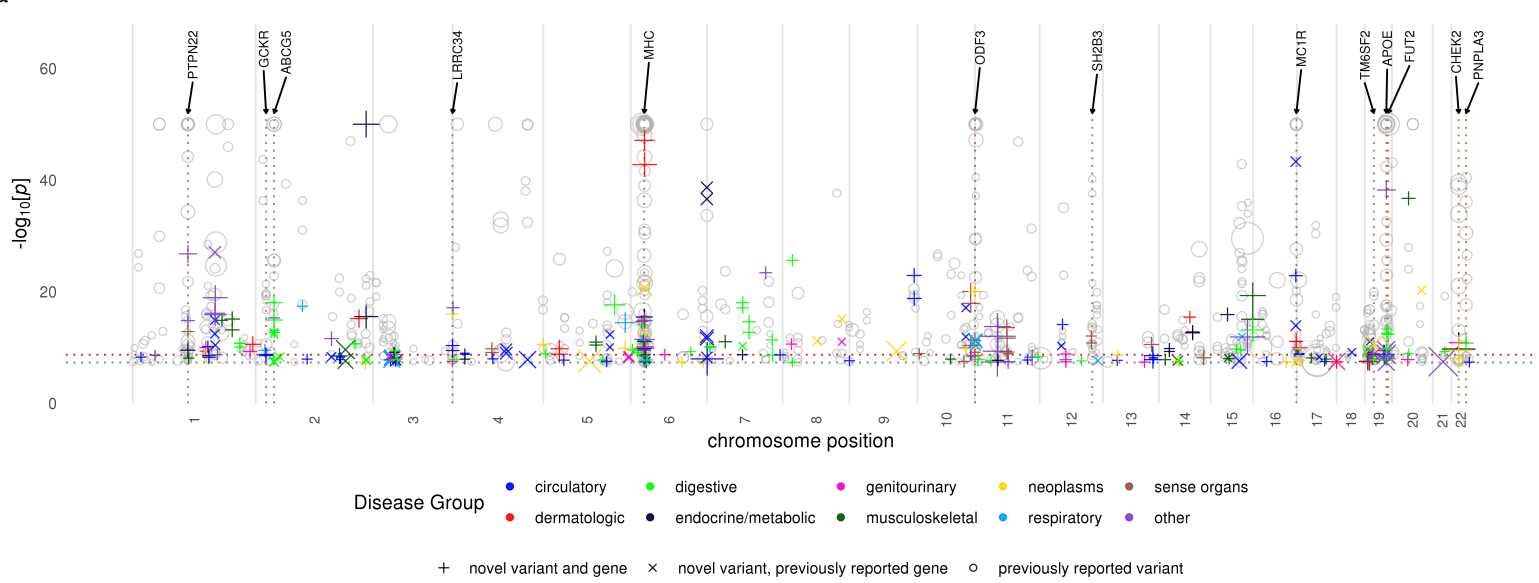

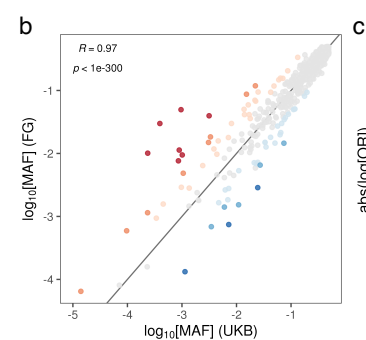

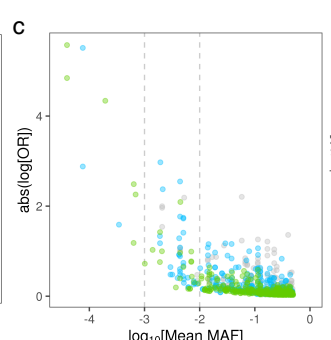

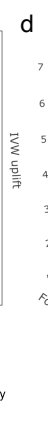

d
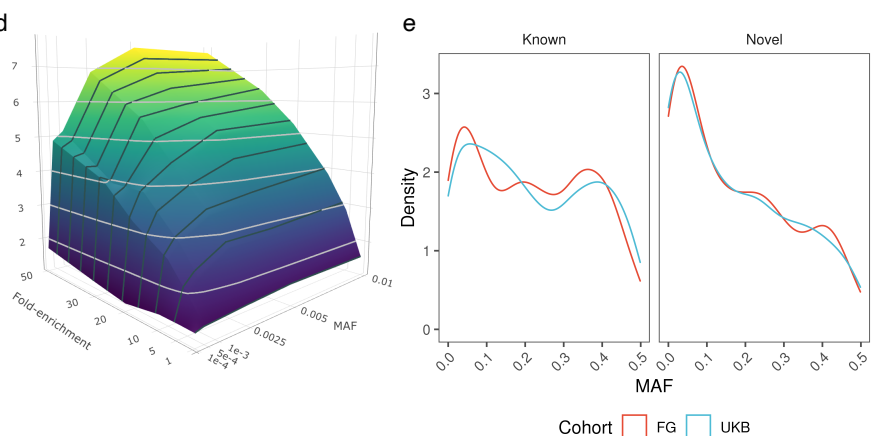
medRxiv preprint doi: https://doi.org/10.1101/2021.10.14.21265023; this version posted October 16, 2021. The copyright holder for this preprint (which was not certified by peer review) is the author/funder, who has granted medRxiv a license to display the preprint in It is made available under a CC-BY-NC-ND 4.0 International license.

Figure 2. (a) Simplified diagram of the coagulation cascade. Factors (in roman numerals, "a" represents activated) with genetic association with $\mathrm{PE}$ highlighted in orange. Blue line (round end) indicates inhibitory effect of APC on VIIIa and Va. (b) Schematic of potential pathway from missense variants in $\boldsymbol{F 5}$ and $\boldsymbol{F 1 0}$ to PE risk. Factor V Leiden variant had null associations with F5 levels $\left(\beta_{\mathrm{F} 5}\right.$ levels $\left.=0.21, p=0.091\right)$. Dashed blue lines suggest effect of the variants on PE risk which we assume under MR framework acts through factor levels (solid blue lines). Grey box and arrows represent known pathway for Factor $\mathrm{V}$ Leiden mutation.

740 GOF: Gain of function, APC: Activated protein C, MR: Mendelian randomisation, PE: Pulmonary embolism.

742
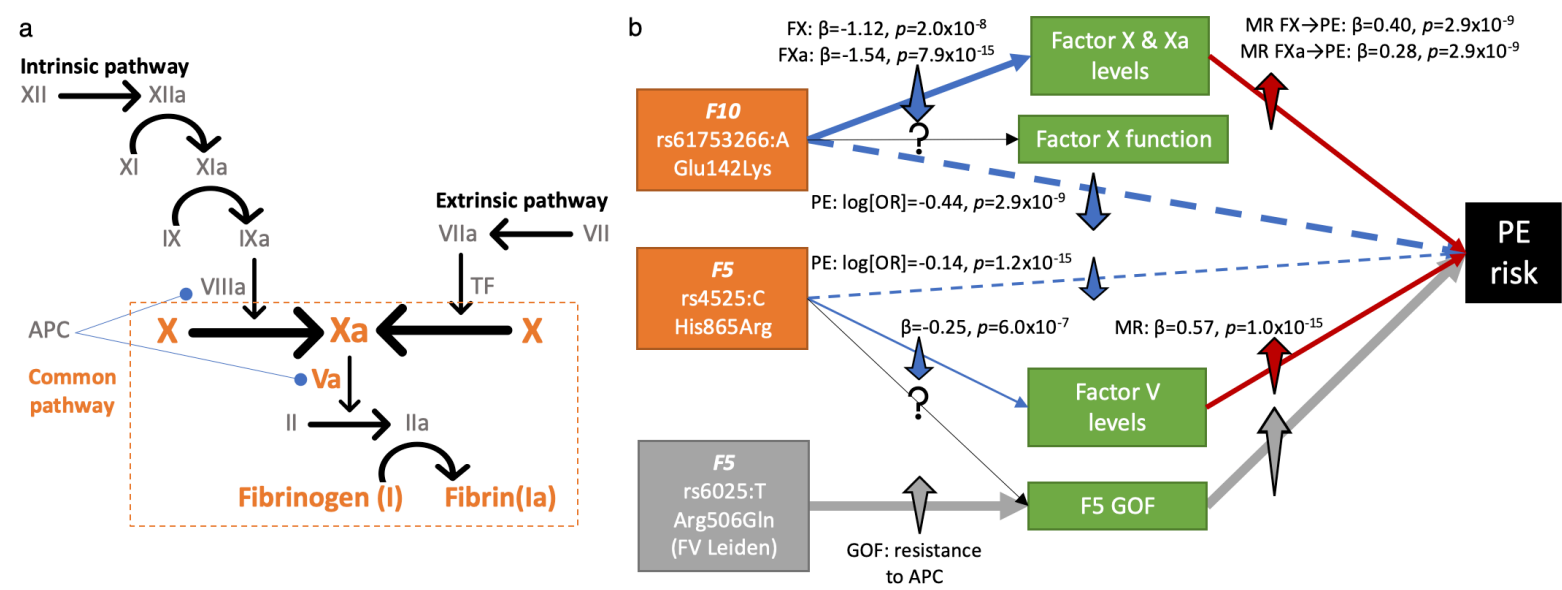
medRxiv preprint doi: https://doi.org/10.1101/2021.10.14.21265023; this version posted October 16, 2021. The copyright holder for this preprint (which was not certified by peer review) is the author/funder, who has granted medRxiv a license to display the preprint in It is made available under a CC-BY-NC-ND 4.0 International license.

Figure 3. Biomarker associations with sentinel variants. (a) Heatmap of sentinel associations with biomarkers. Only significant associations $\left(p<10^{-6}\right)$ displayed. Left side indicates chromosome with cyan indicating MHC region. Right-side: sentinel association with disease by group (colours). Top colours: category of biomarkers. (b) Forest plot of associations between SLC34A1 deletion (rs1460573878) with haematological and biochemistry biomarkers. $P<0.05$ displayed. (c) Forest plot of associations between $\mathrm{CHEK} 2$ deletion (rs555607708) with haematological biomarkers.

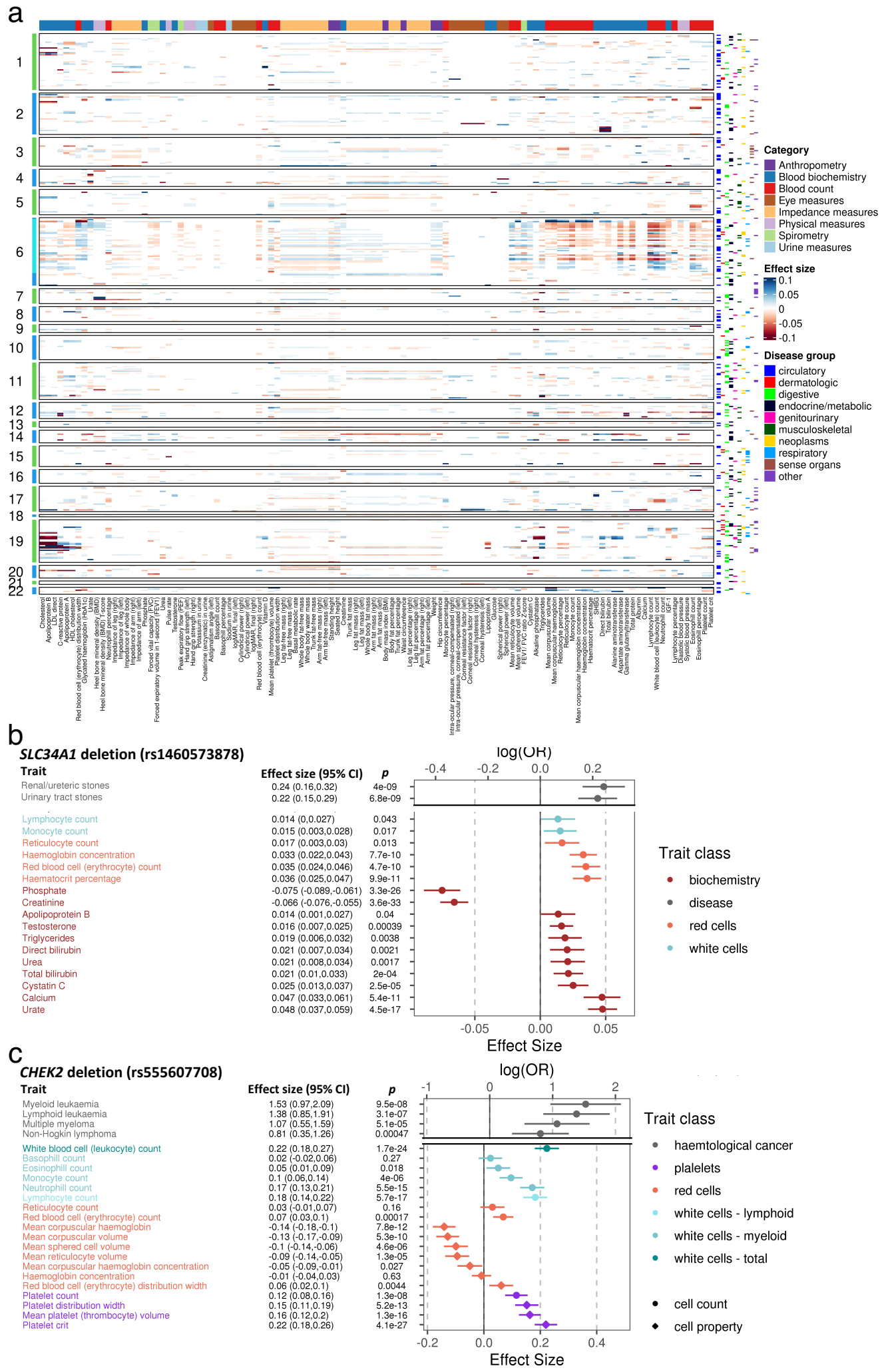


medRxiv preprint doi: https://doi.org/10.1101/2021.10.14.21265023; this version posted October 16, 2021. The copyright holder for this preprint (which was not certified by peer review) is the author/funder, who has granted medRxiv a license to display the preprint in It is made available under a CC-BY-NC-ND 4.0 International license .

Figure 4. Genetic and functional insights into AF.

(a) Clustered MR plot of AF loci on pulse rate. Only variants with cluster inclusion probability $>0.7$ are included. Left to right: CWAS loci (sentinels), Overlapping CWAS and AF GWAS loci, All AF GWAS loci from Nielsen et al. (with zoomed inset), All AF GWAS loci with permuted pulse (null, with zoomed inset). (b) Functional effect of PITX2c Pro41Ser variant (rs143452464) in vitro. Left: schematic of the location of the Pro41Ser variant in PITX2c as compared to the PITX2a splicing alternative. AD1: common sequence, HD: homeodomain, ID1: transcriptional inhibitory domain 1, AD2: second common sequence, ID2: transcriptional inhibitory domain 2. Pro41Ser is within the Nterminal domain (grey), near to the 5-AA sequence (33 to 37 red, LAMAS) important for transcriptional activity of the N-terminal of PITX2c. Middle: Reporter gene assays in TM-1 cells. Luciferase values from activation of the SLC13A3-reporter plasmids $(n=3)$ were normalized to $\beta$-galactosidase (expressed from the transfection control plasmid), relative to the ratio for empty expression vector plus non-deleted SLC13A3 reporter ("-163/+165"). The reporter plasmid designated as "-163/+165 " contains a deletion of $8 \mathrm{bp}$ corresponding to the predicted PITX2 binding site. Right: qRT-PCR analysis of HL-1 cells transfected with PITX2c recombinant plasmids. Effect of Pro41Ser PITX2c variant expression on $\mathrm{Cx} 40, \mathrm{Cx} 43, \mathrm{KCNQ} 1, \mathrm{KCNH} 2, \mathrm{SCN} 1 \mathrm{~B}$ and $\mathrm{SCN} 5 \mathrm{~A} .{ }^{*} p<0.05,{ }^{* *} p<0.01$.
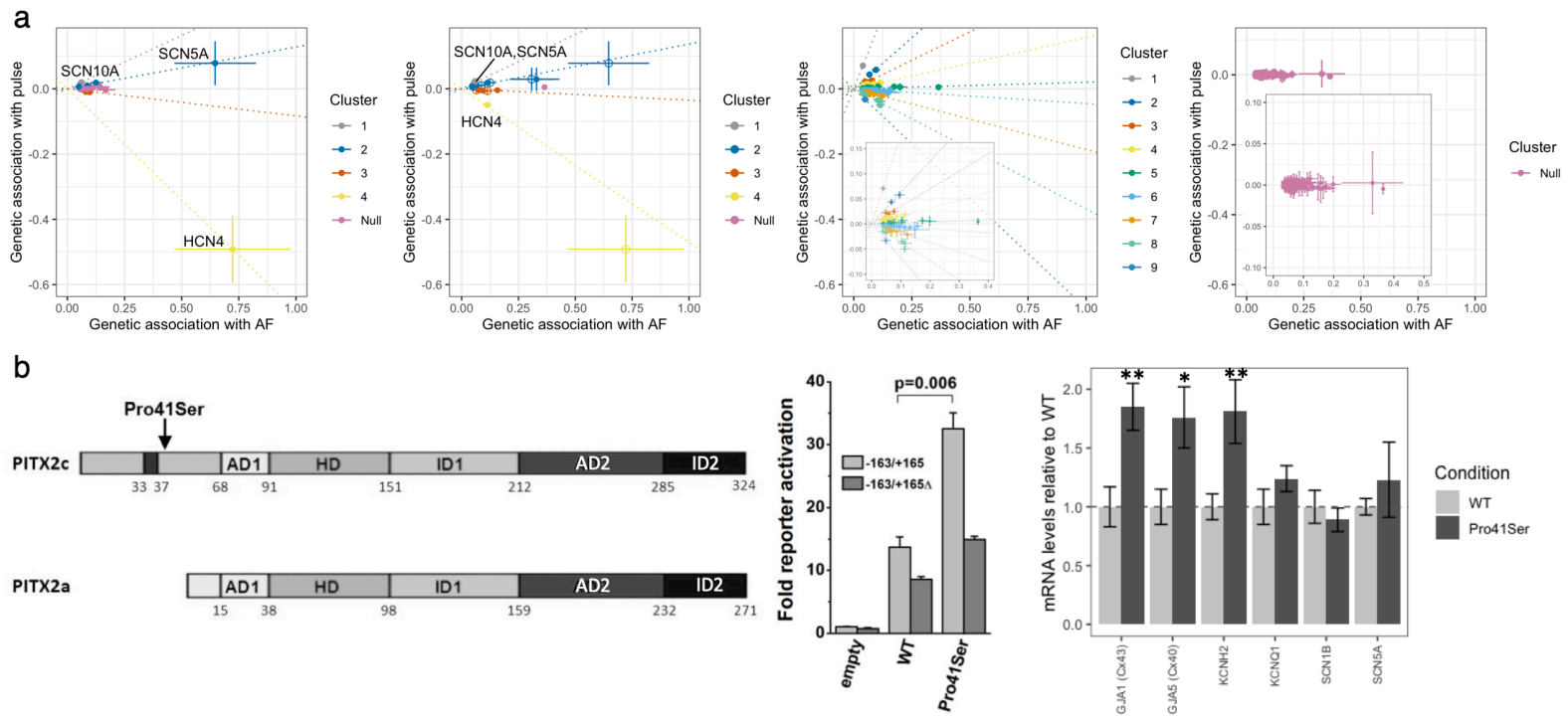
medRxiv preprint doi: https://doi.org/10.1101/2021.10.14.21265023; this version posted October 16, 2021. The copyright holder for this preprint (which was not certified by peer review) is the author/funder, who has granted medRxiv a license to display the preprint in

It is made available under a CC-BY-NC-ND 4.0 International license .

773 Table 1. Genes with sentinel variants enriched $>4$ fold in either UKB or FG. All

774 enrichment $p<5 \times 10^{-5}$.

\begin{tabular}{|c|c|c|c|c|c|c|c|}
\hline Gene & rsID (protein change) & CHR & A0/A1 & $\begin{array}{c}\text { A1 freq } \\
\text { UKB/FG\% }\end{array}$ & \begin{tabular}{|c|} 
log2 FE \\
(FG/UKB)
\end{tabular} & $\begin{array}{l}\text { OMIM gene phenotype } \\
\text { relationships }\end{array}$ & CWAS gene phenotype relationships \\
\hline CHEK2 & $\begin{array}{l}\text { rs17879961 (I200T) } \\
\text { rs555607708 (T410fs) }\end{array}$ & 22 & $\begin{array}{l}A / G \\
A G /-\end{array}$ & $\begin{array}{l}0.04 / 2.99 \% \\
0.24 / 0.64 \%\end{array}$ & $\begin{array}{l}6.25 \\
1.42\end{array}$ & $\begin{array}{l}\text { Cancer (breast, prostate, } \\
\text { colorectal, osteosarcoma); Li- } \\
\text { Fraumeni syndrome }\end{array}$ & $\begin{array}{l}\text { rs17879961:G - benign meningeal } \\
\text { neoplasm } \\
\text { rs555607708:del ( } 2.8 \times \text { FG enriched) - } \\
\text { Cancer (breast, thyroid, colorectal } \\
\text { (benign)); uterine leiomyoma; ovarian } \\
\text { cysts; PCOS }\end{array}$ \\
\hline$D B H$ & rs77273740 (R79W) & 9 & $\mathrm{C} / \mathrm{T}$ & $0.10 / 4.95 \%$ & 5.69 & Orthostatic hypotension & Hypertension (IA) \\
\hline PITX2 & rs143452464 (P41S) & 4 & $\mathrm{G} / \mathrm{A}$ & $0.02 / 1.01 \%$ & 5.42 & $\begin{array}{l}\text { Anterior segment dysgenesis; } \\
\text { Axenfeld-Rieger syndrome, ring } \\
\text { dermoid of cornea }\end{array}$ & Arrythmia and $\mathrm{AF}$ \\
\hline SLC24A5 & rs1426654 (T111A) & 15 & $A / G$ & $0.09 / 1.13 \%$ & 3.67 & $\begin{array}{l}\text { Skin/hair/eye pigmentation } \\
\text { (dark); oculocutaneous albinism }\end{array}$ & $\begin{array}{l}\text { Non-epithelial cancer of skin (other) } \\
\text { (IA) }\end{array}$ \\
\hline CFHR5 & rs565457964 (E163fs) & 1 & C/CAA & $0.32 / 3.96 \%$ & 3.66 & $\begin{array}{l}\text { Nephropathy due to CFHR5 } \\
\text { deficiency }\end{array}$ & $\begin{array}{l}\text { Degeneration of macula and posterior } \\
\text { pole of retina (IA) }\end{array}$ \\
\hline ANKH & rs146886108 (R187Q) & 5 & $C / T$ & $0.72 / 0.07 \%$ & -3.28 & $\begin{array}{l}\text { Chondrocalcinosis; } \\
\text { craniometaphyseal dysplasia }\end{array}$ & Type 2 diabetes mellitus (IA) \\
\hline ALDH16A1 & rs150414818 (P527R) & 19 & C/G & $0.10 / 0.95 \%$ & 3.23 & - & Gout \\
\hline LRRK1 & rs41531245 (T967M) & 15 & $c / T$ & $0.09 / 0.76 \%$ & 3.15 & - & $\begin{array}{l}\text { Contracture of palmar fascia; fasciitis; } \\
\text { umbilical hernia }\end{array}$ \\
\hline CFI & rs141853578 (G119R) & 4 & $\mathrm{C} / \mathrm{T}$ & $0.11 / 0.01 \%$ & -3.10 & $\begin{array}{l}\text { Atypical haemolytic uremic } \\
\text { syndrome; age-related macular } \\
\text { degeneration; CFI deficiency }\end{array}$ & Retinal disorders (other) \\
\hline FLG & $\begin{array}{l}\text { rs61816761 (R501*) } \\
\text { rs } 138381300^{1} \text { (S761fs) }\end{array}$ & 1 & $\begin{array}{c}\text { G/A } \\
\text { CACTG/- }\end{array}$ & \begin{tabular}{|l|}
$2.45 / 0.29 \%$ \\
$2.45 / 1.35 \%$
\end{tabular} & $\begin{array}{l}-3.10 \\
-0.85\end{array}$ & $\begin{array}{l}\text { Atopic dermatitis; ichthyosis } \\
\text { vulgaris }\end{array}$ & $\begin{array}{l}\text { rs61816761:A - dermatitis (other) } \\
\text { rs138381300:del (1.8x UKB enriched) } \\
\text { - asthma; non-epithelial cancer of skin } \\
\text { (other) }\end{array}$ \\
\hline sos2 & rs72681869 (P191R) & 14 & $\mathrm{G} / \mathrm{C}$ & $1.09 / 0.15 \%$ & -2.84 & Noonan syndrome & Hypertension (IA) \\
\hline$X P A$ & rs144725456 (H244R) & 9 & $T / C$ & $0.01 / 0.06 \%$ & 2.61 & Xeroderma pigmentosum & Non-epithelial cancer of skin (other) \\
\hline CDC25A & rs146179438 (Q24H) & 3 & C/A & $1.52 / 8.72 \%$ & 2.52 & - & Kidney and urinary stones (IA) \\
\hline F10 & rs61753266 (E142K) & 13 & G/A & $0.33 / 1.83 \%$ & 2.46 & Factor $\mathrm{X}$ deficiency & $\begin{array}{l}\text { PE and pulmonary heart disease } \\
\text { (inverse association) }\end{array}$ \\
\hline$T N X B$ & $\begin{array}{l}\text { rs61745355 (G2848R) } \\
\text { rs109472301 (R2704H) } \\
\text { rs1150752 }{ }^{1}(\mathrm{~T} 302 \mathrm{~A})\end{array}$ & 6 & $\begin{array}{l}C / T \\
C / T \\
T / C\end{array}$ & $\begin{array}{l}2.22 / 11.86 \% \\
5.96 / 14.75 \% \\
13.29 / 9.17 \%\end{array}$ & $\begin{array}{r}2.42 \\
1.31 \\
-0.54\end{array}$ & $\begin{array}{l}\text { Ehlers-Danlos syndrome; } \\
\text { vesicoureteral reflux }\end{array}$ & $\begin{array}{l}\text { rs61745355:T - lymphoma } \\
\text { rs10947230:T - lichen planus } \\
\text { rs1150752:C - chronic hepatitis; other } \\
\text { inflammatory liver diseases; } \\
\text { atherosclerosis }\end{array}$ \\
\hline SLC39A8 & rs13107325 (A391T) & 4 & $\mathrm{C} / \mathrm{T}$ & $7.40 / 1.46 \%$ & -2.35 & $\begin{array}{l}\text { Congenital disorder of } \\
\text { glycosylation }\end{array}$ & Shoulder lesions \\
\hline CLPTM1 & rs150484293 (L140F) & 19 & $C / T$ & $0.35 / 0.07 \%$ & -2.33 & - & Dementia \\
\hline ELL2 & rs141299831 (S18L) & 5 & G/A & $0.02 / 0.12 \%$ & 2.29 & - & $\begin{array}{l}\text { Benign neoplasm of other and ill- } \\
\text { defined parts of digestive system }\end{array}$ \\
\hline CASP7 & rs141266925 (F214L) & 10 & $T / C$ & $0.31 / 1.5 \%$ & 2.29 & - & Cataracts \\
\hline BRCA1 & rs80357906 (Q1777fs) & 17 & T/TG & $0.001 / 0.01 \%$ & 2.21 & $\begin{array}{l}\text { Cancer (breast, ovarian, } \\
\text { pancreatic); Fanconi anaemia }\end{array}$ & Breast cancer \\
\hline SCN5A & rs45620037 (T220I) & 3 & $\mathrm{G} / \mathrm{A}$ & $0.11 / 0.49 \%$ & 2.20 & $\begin{array}{l}\text { Sudden infant death syndrome; } \\
\text { dilated cardiomyopathy; } \\
\text { arrythmia }\end{array}$ & Arrythmia and $\mathrm{AF}$ \\
\hline CACNA1D & $\begin{array}{l}\text { rs1250342280 } \\
\text { (F1943del) }\end{array}$ & 3 & $\mathrm{CCTT/C}$ & $0.60 / 0.14 \%$ & -2.09 & $\begin{array}{l}\text { Primary aldosteronism, seizures, } \\
\text { and neurologic abnormalities; } \\
\text { sinoatrial node dysfunction and } \\
\text { deafness }\end{array}$ & Hypertension \\
\hline WNT1OA & rs121908120 (F228I) & 2 & T/A & $2.72 / 0.65 \%$ & -2.06 & $\begin{array}{l}\text { Odontoonychodermal dysplasia; } \\
\text { Schopf-Schulz-Passarge } \\
\text { syndrome; selective tooth } \\
\text { agenesis }\end{array}$ & $\begin{array}{l}\text { Follicular cysts of skin and } \\
\text { subcutaneous tissue (IA) }\end{array}$ \\
\hline
\end{tabular}

${ }^{1}$ Other sentinel variants in the gene with $<4 \mathrm{FE}$

2Sudden infant death syndrome; atrial fibrillation; Brugada syndrome; progressive and non-progressive heart block; long QT syndrome, sick sinus syndrome; ventricular fibrillation

FE: fold enrichment; IA: inverse association; PCOS: polycystic ovarian syndrome; PE: pulmonary embolism; AF: atrial 780 fibrillation 
medRxiv preprint doi: https://doi.org/10.1101/2021.10.14.21265023; this version posted October 16, 2021. The copyright holder for this preprint (which was not certified by peer review) is the author/funder, who has granted medRxiv a license to display the preprint in It is made available under a CC-BY-NC-ND 4.0 International license

\section{References}

7831 Claussnitzer, M. et al. A brief history of human disease genetics. Nature 577, 179189, doi:10.1038/s41586-019-1879-7 (2020).

2 Bycroft, C. et al. The UK Biobank resource with deep phenotyping and genomic data. Nature 562, 203-209, doi:10.1038/s41586-018-0579-z (2018).

3 Van Hout, C. V. et al. Exome sequencing and characterization of 49,960 individuals in the UK Biobank. Nature 586, 749-756, doi:10.1038/s41586-020-2853-0 (2020). Szustakowski, J. D. et al. Advancing Human Genetics Research and Drug Discovery through Exome Sequencing of the UK Biobank. medRxiv, 2020.2011.2002.20222232, doi:10.1101/2020.11.02.20222232 (2020). Wang, Q. et al. Surveying the contribution of rare variants to the genetic architecture of human disease through exome sequencing of 177,882 UK Biobank participants. bioRxiv, 2020.2012.2013.422582, doi:10.1101/2020.12.13.422582 (2020). Peltonen, L., Jalanko, A. \& Varilo, T. Molecular genetics of the Finnish disease heritage. Hum Mol Genet 8, 1913-1923, doi:10.1093/hmg/8.10.1913 (1999). Lim, E. T. et al. Distribution and medical impact of loss-of-function variants in the Finnish founder population. PLoS Genet 10, e1004494, doi:10.1371/journal.pgen.1004494 (2014). Locke, A. E. et al. Exome sequencing of Finnish isolates enhances rare-variant association power. Nature 572, 323-328, doi:10.1038/s41586-019-1457-z (2019).

803

804 Hassan, S. et al. High-resolution population-specific recombination rates and their effect on phasing and genotype imputation. Eur J Hum Genet, doi:10.1038/s41431020-00768-8 (2020).

10 Buniello, A. et al. The NHGRI-EBI GWAS Catalog of published genome-wide association studies, targeted arrays and summary statistics 2019. Nucleic acids research 47, D1005-D1012, doi:10.1093/nar/gky1120 (2019). Staley, J. R. et al. PhenoScanner: a database of human genotype-phenotype associations. Bioinformatics (Oxford, England) 32, 3207-3209, doi:10.1093/bioinformatics/btw373 (2016).

812

Landrum, M. J. et al. ClinVar: improving access to variant interpretations and supporting evidence. Nucleic acids research 46, D1062-D1067, doi:10.1093/nar/gkx1153 (2018).

13 Sun, B. B. et al. Genomic atlas of the human plasma proteome. Nature 558, 73-79, doi:10.1038/s41586-018-0175-2 (2018).

14 Forberg, E., Huhmann, I., Jimenez-Boj, E. \& Watzke, H. H. The impact of Glu102Lys on the factor $\mathrm{X}$ function in a patient with a doubly homozygous factor $\mathrm{X}$ deficiency (Gla14Lys and Glu102Lys). Thromb Haemost 83, 234-238 (2000). Suhre, K. et al. Connecting genetic risk to disease end points through the human blood plasma proteome. Nat Commun 8, 14357-14357, doi:10.1038/ncomms 14357 (2017).

16 Kujovich, J. L. Factor V Leiden thrombophilia. Genetics in Medicine 13, 1-16, doi:10.1097/GIM.0b013e3181 faa0f2 (2011).

17 de Vries, P. S. et al. A meta-analysis of 120246 individuals identifies 18 new loci for fibrinogen concentration. Hum Mol Genet 25, 358-370, doi:10.1093/hmg/ddv454 (2016).

18 Wassel, C. L. et al. Association of genomic loci from a cardiovascular gene SNP array with fibrinogen levels in European Americans and African-Americans from six 
medRxiv preprint doi: https://doi.org/10.1101/2021.10.14.21265023; this version posted October 16, 2021. The copyright holder for this preprint (which was not certified by peer review) is the author/funder, who has granted medRxiv a license to display the preprint in It is made available under a CC-BY-NC-ND 4.0 International license

cohort studies: the Candidate Gene Association Resource (CARe). Blood 117, 268275, doi:10.1182/blood-2010-06-289546 (2011).

19 Simurda, T. et al. Genetic Variants in the FGB and FGG Genes Mapping in the Beta and Gamma Nodules of the Fibrinogen Molecule in Congenital Quantitative Fibrinogen Disorders Associated with a Thrombotic Phenotype. Int J Mol Sci 21, doi:10.3390/ijms21134616 (2020).

20 Lapointe, J. Y. et al. NPT2a gene variation in calcium nephrolithiasis with renal phosphate leak. Kidney Int 69, 2261-2267, doi:10.1038/sj.ki.5000437 (2006).

21 Halbritter, J. et al. Fourteen monogenic genes account for $15 \%$ of nephrolithiasis/nephrocalcinosis. J Am Soc Nephrol 26, 543-551, doi:10.1681/ASN.2014040388 (2015).

22 Schlingmann, K. P. et al. Autosomal-Recessive Mutations in SLC34A1 Encoding Sodium-Phosphate Cotransporter 2A Cause Idiopathic Infantile Hypercalcemia. J Am Soc Nephrol 27, 604-614, doi:10.1681/ASN.2014101025 (2016).

23 Hinds, D. A. et al. Germ line variants predispose to both JAK2 V617F clonal hematopoiesis and myeloproliferative neoplasms. Blood 128, 1121-1128, doi:10.1182/blood-2015-06-652941 (2016).

24 Sellick, G. S., Sullivan, K., Catovsky, D. \& Houlston, R. S. CHEK2*1100delC and risk of chronic lymphocytic leukemia. Leuk Lymphoma 47, 2659-2660, doi:10.1080/10428190600942462 (2006).

25 Yan, K. et al. Normal platelet counts mask abnormal thrombopoiesis in patients with chronic myeloid leukemia. Oncol Lett 10, 2390-2394, doi:10.3892/ol.2015.3502 (2015).

26 Wang, Y. et al. Therapeutic target database 2020: enriched resource for facilitating research and early development of targeted therapeutics. Nucleic Acids Res $\mathbf{4 8 ,}$ D1031-D1041, doi:10.1093/nar/gkz981 (2020).

27 Nelson, M. R. et al. The support of human genetic evidence for approved drug indications. Nat Genet 47, 856-860, doi:10.1038/ng.3314 (2015).

28 King, E. A., Davis, J. W. \& Degner, J. F. Are drug targets with genetic support twice as likely to be approved? Revised estimates of the impact of genetic support for drug mechanisms on the probability of drug approval. PLoS Genet 15, e1008489, doi:10.1371/journal.pgen.1008489 (2019).

29 Võsa, U. et al. Unraveling the polygenic architecture of complex traits using blood eQTL metaanalysis. bioRxiv, 447367, doi:10.1101/447367 (2018).

30 Girotra, M. et al. The Current Understanding of the Endocrine Effects From Immune Checkpoint Inhibitors and Recommendations for Management. JNCI Cancer Spectr 2, pky021, doi:10.1093/jncics/pky021 (2018).

31 Diogo, D. et al. Phenome-wide association studies across large population cohorts support drug target validation. Nat Commun 9, 4285, doi:10.1038/s41467-018-065403 (2018).

32 Nielsen, J. B. et al. Biobank-driven genomic discovery yields new insight into atrial fibrillation biology. Nature Genetics 50, 1234-1239, doi:10.1038/s41588-018-0171-3 (2018).

33 Roselli, C. et al. Multi-ethnic genome-wide association study for atrial fibrillation. Nature genetics 50, 1225-1233, doi:10.1038/s41588-018-0133-9 (2018).

34 Thorolfsdottir, R. B. et al. A Missense Variant in PLEC Increases Risk of Atrial Fibrillation. J Am Coll Cardiol 70, 2157-2168, doi:10.1016/j.jacc.2017.09.005 (2017).

35 Petkowski, J. J. et al. NRMT2 is an N-terminal monomethylase that primes for its homologue NRMT1. Biochem J 456, 453-462, doi:10.1042/BJ20131163 (2013). 
medRxiv preprint doi: https://doi.org/10.1101/2021.10.14.21265023; this version posted October 16, 2021. The copyright holder for this preprint (which was not certified by peer review) is the author/funder, who has granted medRxiv a license to display the preprint in It is made available under a CC-BY-NC-ND 4.0 International license .

36 Dong, C. et al. An asparagine/glycine switch governs product specificity of human Nterminal methyltransferase NTMT2. Commun Biol 1, 183, doi:10.1038/s42003-0180196-2 (2018).

37 Consortium, G. T. The Genotype-Tissue Expression (GTEx) project. Nat Genet 45, 580-585, doi:10.1038/ng.2653 (2013).

38 Uhlen, M. et al. Proteomics. Tissue-based map of the human proteome. Science 347, 1260419, doi:10.1126/science.1260419 (2015).

39 Feghaly, J., Zakka, P., London, B., MacRae, C. A. \& Refaat, M. M. Genetics of Atrial Fibrillation. J Am Heart Assoc 7, e009884, doi:10.1161/JAHA.118.009884 (2018).

40 Chambers, J. C. et al. Genetic variation in SCN10A influences cardiac conduction. Nat Genet 42, 149-152, doi:10.1038/ng.516 (2010).

41 Li, W. et al. SCN5A Variants: Association With Cardiac Disorders. Front Physiol 9, 1372, doi:10.3389/fphys.2018.01372 (2018).

42 Gui, J. et al. Multiple loss-of-function mechanisms contribute to SCN5A-related familial sick sinus syndrome. PLoS One 5, e10985, doi:10.1371/journal.pone.0010985 (2010).

43 Benson, D. W. et al. Congenital sick sinus syndrome caused by recessive mutations in the cardiac sodium channel gene (SCN5A). J Clin Invest 112, 1019-1028, doi:10.1172/JCI18062 (2003).

44 Olson, T. M. et al. Sodium channel mutations and susceptibility to heart failure and atrial fibrillation. JAMA 293, 447-454, doi:10.1001/jama.293.4.447 (2005).

45 Zaklyazminskaya, E. \& Dzemeshkevich, S. The role of mutations in the SCN5A gene in cardiomyopathies. Biochim Biophys Acta 1863, 1799-1805, doi:10.1016/j.bbamcr.2016.02.014 (2016).

46 Verkerk, A. O. \& Wilders, R. Pacemaker activity of the human sinoatrial node: effects of HCN4 mutations on the hyperpolarization-activated current. Europace 16, 384-395, doi:10.1093/europace/eut348 (2014).

47 Foley, C. N., Mason, A. M., Kirk, P. D. W. \& Burgess, S. MR-Clust: Clustering of genetic variants in Mendelian randomization with similar causal estimates. Bioinformatics, doi:10.1093/bioinformatics/btaa778 (2020).

48 Sidhu, S. \& Marine, J. E. Evaluating and managing bradycardia. Trends Cardiovasc Med 30, 265-272, doi:10.1016/j.tcm.2019.07.001 (2020).

49 Syeda, F., Kirchhof, P. \& Fabritz, L. PITX2-dependent gene regulation in atrial fibrillation and rhythm control. J Physiol 595, 4019-4026, doi:10.1113/JP273123 (2017).

50 Ripke, S., Walters, J. T. \& O’Donovan, M. C. Mapping genomic loci prioritises genes and implicates synaptic biology in schizophrenia. medRxiv, 2020.2009.2012.20192922, doi:10.1101/2020.09.12.20192922 (2020).

51 Eichler, E. E. et al. Missing heritability and strategies for finding the underlying causes of complex disease. Nat Rev Genet 11, 446-450, doi:10.1038/nrg2809 (2010).

52 Howles, S. A. \& Thakker, R. V. Genetics of kidney stone disease. Nat Rev Urol 17, 407-421, doi:10.1038/s41585-020-0332-x (2020).

53 Plenge, R. M., Scolnick, E. M. \& Altshuler, D. Validating therapeutic targets through human genetics. Nat Rev Drug Discov 12, 581-594, doi:10.1038/nrd4051 (2013).

54 Denny, J. C. et al. Systematic comparison of phenome-wide association study of electronic medical record data and genome-wide association study data. Nat Biotechnol 31, 1102-1110, doi:10.1038/nbt.2749 (2013).

55 Kosmicki, J. A. et al. A catalog of associations between rare coding variants and COVID-19 outcomes. medRxiv, 2020.2010.2028.20221804, doi:10.1101/2020.10.28.20221804 (2021). 
medRxiv preprint doi: https://doi.org/10.1101/2021.10.14.21265023; this version posted October 16, 2021. The copyright holder for this preprint (which was not certified by peer review) is the author/funder, who has granted medRxiv a license to display the preprint in perpetuity.

It is made available under a CC-BY-NC-ND 4.0 International license .

$92856 \quad$ Karczewski, K. J. et al. The mutational constraint spectrum quantified from variation in 141,456 humans. Nature 581, 434-443, doi:10.1038/s41586-020-2308-7 (2020).

93057 McLaren, W. et al. The Ensembl Variant Effect Predictor. Genome Biol 17, 122,

931 doi:10.1186/s13059-016-0974-4 (2016).

932

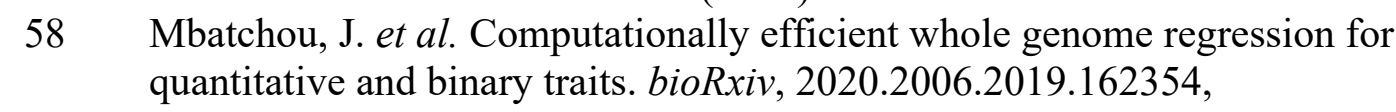

933

934

58 Mbatchou, J. et al. Computationally efficient whole genome reg

59 Zhou, W. et al. Efficiently controlling for case-control imbalance and sample

936

937 relatedness in large-scale genetic association studies. Nat Genet 50, 1335-1341,

938 doi:10.1038/s41588-018-0184-y (2018).

939

60 Willer, C. J., Li, Y. \& Abecasis, G. R. METAL: fast and efficient meta-analysis of genomewide association scans. Bioinformatics 26, 2190-2191,

940

941 doi:10.1093/bioinformatics/btq340 (2010).

942

943

61 Chang, C. C. et al. Second-generation PLINK: rising to the challenge of larger and

944

945

946 richer datasets. Gigascience 4, 7, doi:10.1186/s13742-015-0047-8 (2015).

62 Yates, A. D. et al. Ensembl 2020. Nucleic Acids Res 48, D682-D688, doi:10.1093/nar/gkz966 (2020).

63 Burgess, S., Foley, C. N. \& Zuber, V. Inferring Causal Relationships Between Risk Factors and Outcomes from Genome-Wide Association Study Data. Annu Rev

949 Genomics Hum Genet 19, 303-327, doi:10.1146/annurev-genom-083117-021731 (2018).

950

64 UniProt, C. UniProt: the universal protein knowledgebase in 2021. Nucleic Acids Res 951 49, D480-D489, doi:10.1093/nar/gkaa1100 (2021). 